\title{
AVALIAÇÃO DA EXATIDÃO DE POSICIONAMENTO PLANIMÉTRICO DE UM RECEPTOR GPS OPERANDO SOB DIFERENTES CONDIÇÕES DE COBERTURA VEGETAL
}

\author{
RUBENSANGULO FILHO \\ Engenheiro Agrônomo
}

Tese apresentada à Escola Superior de Agricultura "Luiz de Queiroz" da Universidade de São Paulo, como parte dos requisitos para obtenção do título de Livre-Docente do Departamento de Engenharia Rural, na especialidade / disciplina: Topografia.

\section{PIRACICABA}

Estado de São Paulo - Brasil

Março - 2001 


\title{
SUMÁRIO
}

\begin{abstract}
Página

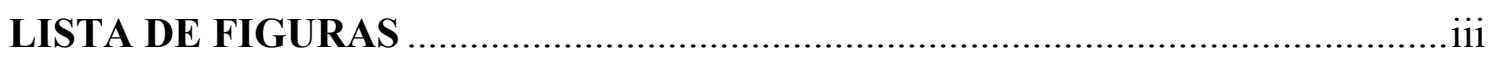

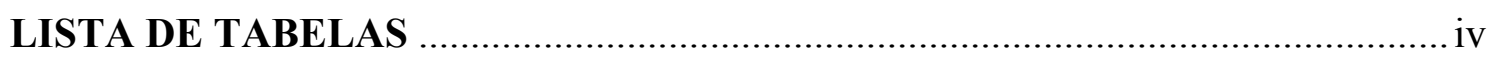

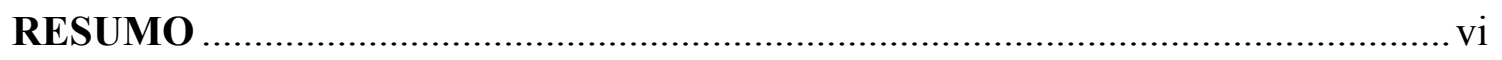

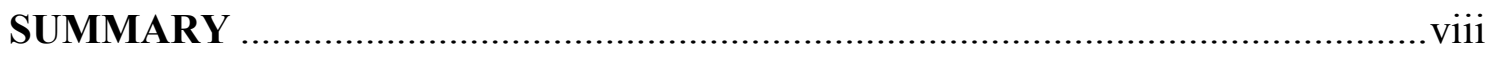

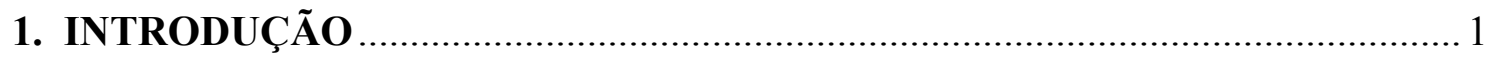

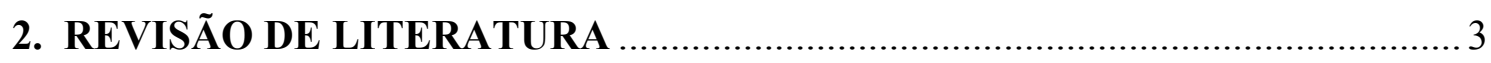

2.1. O Sistema de Posicionamento Global (GPS) .......................................... 3

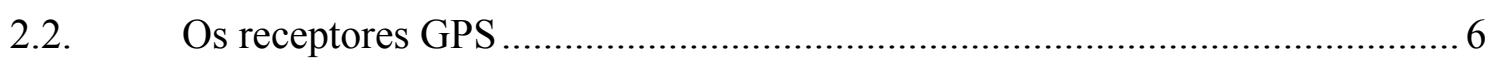

2.3. Métodos de posicionamento com GPS ................................................ 9

2.4. Aplicações nas áreas agrícola e florestal ................................................... 14

2.5. Influência da cobertura vegetal e outros fatores no desempenho do

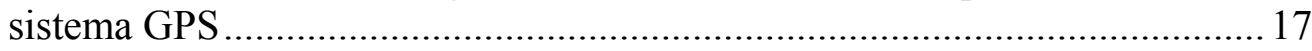

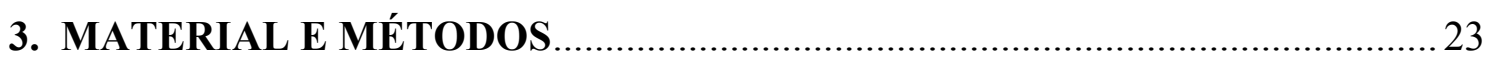

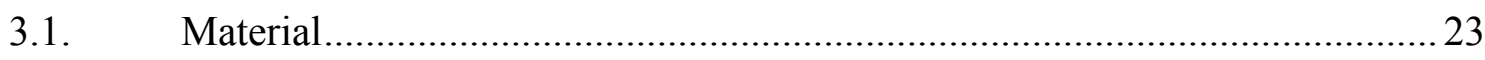

3.1.1. Localização da área de estudo ............................................................ 23

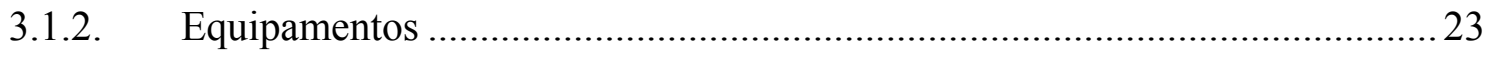

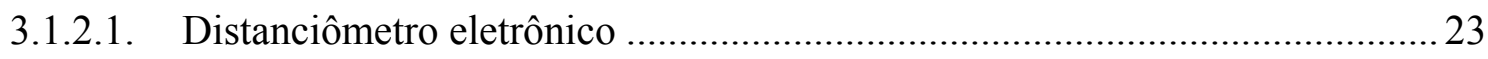

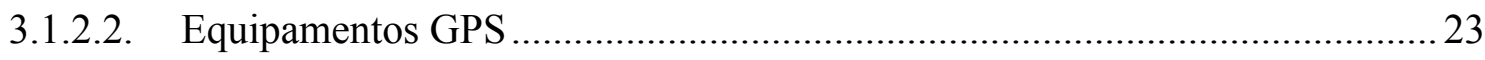

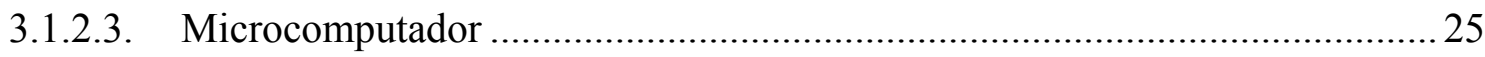

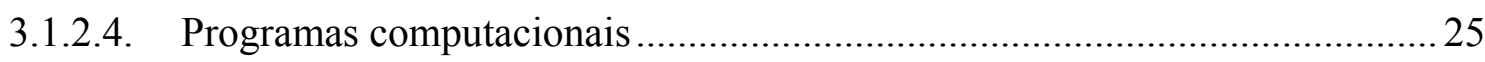

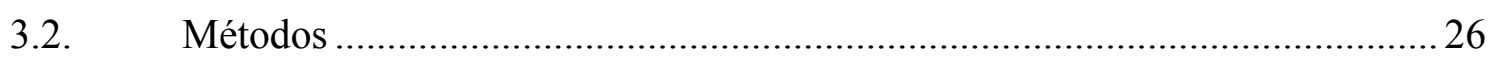

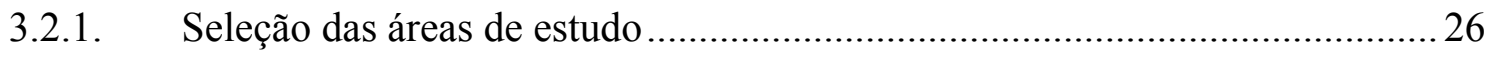

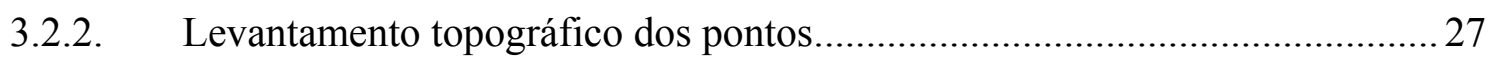

3.2.3. Teste preliminar para avaliação da taxa de aquisição com o receptor GPS ... 28

3.2.4. Levantamento das coordenadas planimétricas dos pontos, com o

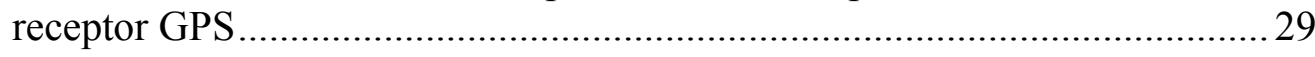




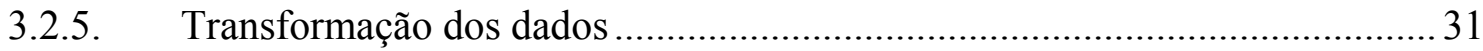

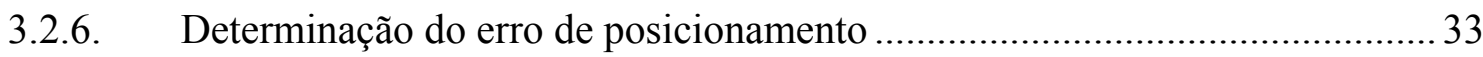

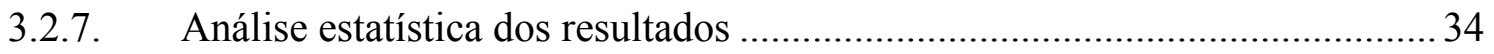

3.2.7.1. Análise da variância e testes de significância............................................... 34

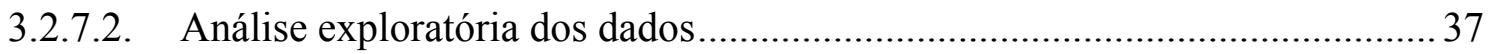

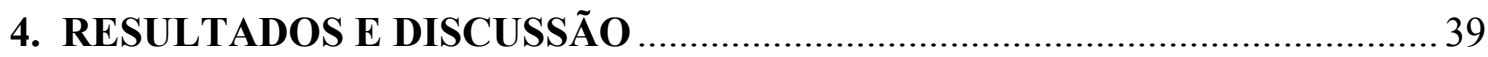

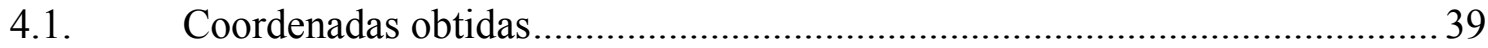

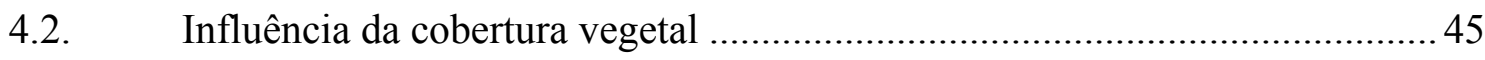

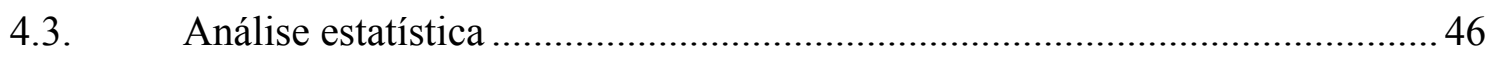

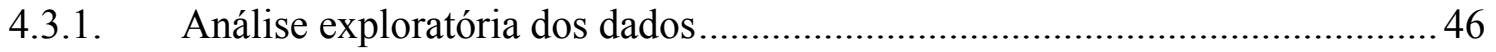

4.3.2. Análise da variância e testes de significância............................................ 48

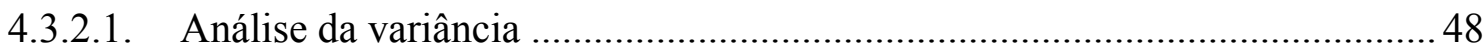

4.3.2.2. Testes de comparação para médias de coberturas vegetais .......................... 49

4.3.2.3. Detalhamento da análise para tempos de medição por meio da análise de regressão polinomial......................................................................... 51

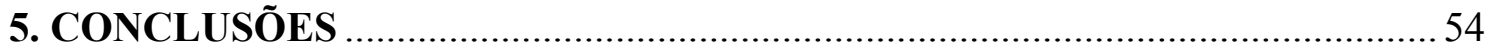

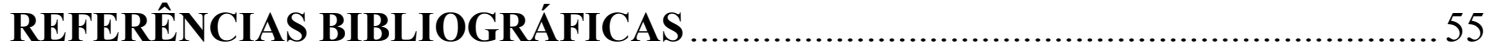




\section{LISTA DE FIGURAS}

1 Estrutura das órbitas dos satélites NAVSTAR/GPS ................................................ 4

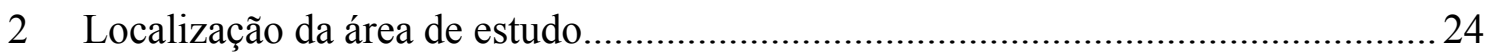

3 Análise gráfica dos resíduos padronizados para a variável erro de posição, sem transformação e com transformação raiz quadrada ................................................ 47

4 Diagrama de ramos e folhas para a variável erro de posição, sem transformação e com transformação raiz quadrada ......................................................................... 47

5 Relação linear entre o fator tempo de medição e a variável de resposta erro de

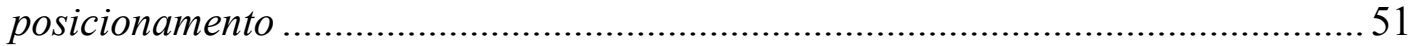

6 Ajuste da relação entre o fator tempo de medição e a variável de resposta erro de posicionamento para cada uma das coberturas vegetais..........................................52 


\section{LISTA DE TABELAS}

Página

1 Classificação dos receptores GPS de acordo com sua exatidão. ............................. 8

2 Técnicas de posicionamento por meio da portadora e SA em funcionamento ........ 11

3 Técnicas de posicionamento por meio do código C/A e SA em funcionamento..... 12

4 Exatidões do método cinemático .................................................................. 13

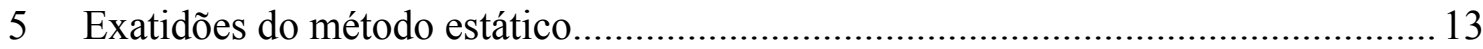

6 Coeficientes técnicos do levantamento planimétrico dos pontos. ..........................28

7 Alguns resultados obtidos no teste preliminar para avaliação da taxa de aquisição de dados e tempo de permanência do equipamento sobre um ponto de controle......... 29

8 Identificação dos pontos utilizados nos levantamentos. ....................................... 34

9 Esquema de análise da variância e teste F para tratamentos................................... 36

10 Coordenadas topográficas e GPS e erro de posicionamento para os pontos levantados na área teste ocupada por pastagem............................................. 41

11 Coordenadas topográficas e GPS e erro de posicionamento para os pontos levantados na área teste ocupada por seringueira.

12 Coordenadas topográficas e GPS e erro de posicionamento para os pontos levantados na área teste ocupada por pinus.

13 Coordenadas topográficas e GPS e erro de posicionamento para os pontos levantados na área teste ocupada por eucalipto. 44

14 Médias de registros de posicionamento armazenados pelo receptor GPS por unidade de tempo 
15 Análise da variância e teste $\mathrm{F}$ para a variável erro de medição (com transformação raiz quadrada), em função dos fatores (causas da variação) cobertura e tempo de medição. 48

16 Comparações entre coberturas vegetais pelo teste de Tukey, baseadas em médias da variável erro de posicionamento

17 Comparações entre coberturas vegetais pelo teste de Dunnett, em médias da variável erro de medição, considerando pastagem como testemunha 50 


\title{
AVALIAÇÃO DA EXATIDÃo DE POSICIONAMENTO PLANIMÉTRICO DE UM RECEPTOR GPS OPERANDO SOB DIFERENTES CONDIÇÕES DE COBERTURA VEGETAL
}

\author{
Autor: RUBENS ANGULO FILHO
}

\section{RESUMO}

O GPS - Sistema de Posicionamento Global, foi desenvolvido pelo Departamento de Defesa dos EUA, originalmente com fins militares estratégicos. A partir de meados da década de setenta o seu uso foi estendido para aplicações civis, tendo passado por uma contínua evolução desde então. Representa atualmente uma nova alternativa de posicionamento para a Geodésia, Cartografia, Topografia e ciências afins, tendo o uso do GPS crescido significativamente em aplicações nas atividades agrícolas e florestais. No Brasil, face à extensão territorial e à escassez de informações georreferenciadas, o GPS mostra-se como um recurso particularmente promissor.

A sua aplicação nas diferentes atividades agrícolas e florestais necessita ainda ter respondida uma série de indagações antes do seu uso generalizado. Uma dessas indagações diz respeito à interferência da cobertura vegetal na recepção dos sinais GPS. Este trabalho foi desenvolvido com o intuito de avaliar esse efeito na exatidão de posicionamento planimétrico. 
A área de estudo encontra-se no Campus "Luiz de Queiroz" da Universidade de São Paulo, no município de Piracicaba, Estado de São Paulo, cujas coordenadas aproximadas são: a) latitude de $22^{\circ} 42^{\prime} 40^{\prime \prime} \mathrm{S}$ e b) longitude de $47^{\circ} 37^{\prime} 30^{\prime \prime}$ WG.

Para avaliar a exatidão do receptor GPS - Trimble/Pro-XL operando sob diferentes condições de cobertura vegetal (pastagem, seringueira, eucalipto e pinus), o equipamento foi posicionado, alternadamente, sobre 6 pontos locados ao acaso (materializados por piquetes e identificados por estacas de madeira) nas áreas de estudo, que tiveram suas coordenadas levantadas pelo método topográfico, segundo a $N B R$ 13133 - Execução de Levantamento Topográfico (poligonais da classe IVP), variando o tempo de permanência ( $1 \mathrm{~min}, 5 \mathrm{~min}$ e $10 \mathrm{~min}$ ), mas com a mesma taxa de aquisição de dados (1 segundo), sendo posteriormente feita a correção diferencial (DGPS) pósprocessada dos dados.

De acordo com a metodologia empregada e os resultados obtidos, as principais conclusões foram: a) foi possível separar as exatidões de posicionamento planimétrico, conforme o tipo de cobertura vegetal, em dois grupos: sem e com cobertura arbórea, confirmando assim a interferência do dossel na recepção dos sinais emitidos pelos satélites GPS; b) o aumento do tempo de permanência, de maneira geral, melhorou a exatidão de posicionamento planimétrico, o que ratifica a escolha da metodologia de levantamento como sendo fundamental para obtenção de bons resultados de posicionamento. 


\title{
PLANIMETRIC ACCURACY EVALUATION OF A GPS RECEIVER UNDER DIFFERENT CONDITIONS OF VEGETATION COVER
}

\author{
Author: RUBENS ANGULO FILHO
}

\section{SUMMARY}

The U. S. Department of Defense originally developed the Global Positioning System-GPS for military purposes. From the 70's on its use was extended to civil purposes and it has been improved since then. Today it is a new positioning alternative to Geodesy, Cartography, Surveying and Applied Sciences. The use of GPS in agriculture and forestry has been increasing continuously. The GPS has been showing a promising resource in Brazil due to its territorial extension and lack of geocoding data.

Many questions on its application in agriculture and forestry must still be answered before its general use. One of these questions is about the vegetation cover interference on the reception of GPS signals. The aim of this work is to evaluate this interference effect on the planimetric positioning accuracy.

The Campus "Luiz de Queiroz" of the University of São Paulo in Piracicaba/São Paulo State-Brazil was chosen as the studying area. This place is located between the following coordinates: a) latitude $22^{\circ} 42^{\prime} 40^{\prime \prime} \mathrm{S}$ and b) longitude $47^{\circ} 37^{\prime} 30^{\prime \prime}$ WG.

To evaluate the GPS receiver - Trimble/Pro-XL accuracy working under different conditions of vegetation cover (pasture, rubber trees, eucalyptus and pine 
trees), 6 control points were located randomly in the studied area. Their coordinates were obtained by a surveying method according to NBR 13133 - Execução de Levantamento Topográfico/Brazilian Surveying Standard. After the GPS receiver was positioned on those control points maintaining the acquisition rate of 1 second, and time was changed to $1 \mathrm{~min}, 5 \mathrm{~min}$ and $10 \mathrm{~min}$. The DGPS method was used to correct the positioning coordinate data.

According to the methodology applied and the obtained results, the main conclusions were: a) it was possible to separate planimetric positioning accuracy, according to the vegetation cover, in two groups: with and without tree canopy, confirming its interference on the receiver signal reception emitted by the GPS satellites; b) the increasing time on the control points improved the planimetric positioning accuracy, which emphasizes the importance of right choice of the surveying methodology to be applied. 


\section{INTRODUÇÃO}

O posicionamento, ou mais especificamente, a localização de pontos topográficos, seres, veículos etc. faz parte das mais variadas atividades humanas, como a Engenharia e os seus diversos ramos, e também Geografia, Geologia, Navegação (terrestre, marítima, aérea e orbital), Cartografia e várias outras mais.

A Geodésia, a Cartografia e a Topografia, vêm experimentando uma grande evolução nas últimas décadas. Contudo, recentemente, ocorreu uma verdadeira revolução na atividade do posicionamento, com a divulgação da utilização do sistema GPS, principalmente a partir da Guerra do Golfo Pérsico em 1991, quando foi amplamente noticiado o fato de soldados americanos poderem determinar rapidamente sua posição sobre um mapa da região, por meio de um equipamento portátil e de simples manuseio.

O GPS - Sistema de Posicionamento Global, foi desenvolvido pelo Departamento de Defesa dos EUA, originalmente com fins militares estratégicos. A partir de meados da década de setenta o seu uso foi estendido para aplicações civis, tendo passado por uma contínua evolução desde então. Representa atualmente uma nova alternativa de posicionamento para a Geodésia, Cartografia, Topografia e ciências afins, tendo o uso do GPS crescido significativamente em aplicações nas atividades agrícolas e florestais. Os EUA têm se destacado pelo pioneirismo e pelos múltiplos tipos de emprego do sistema nessa área, sendo que no Brasil, face à extensão territorial e à escassez de informações georreferenciadas, o GPS mostra-se um recurso particularmente promissor.

A popularização da informática, a partir da década de 90, e de instrumentos poderosos como os Sistemas de Informação Geográfica (SIG), aliada à 
constante evolução da tecnologia GPS, estão possibilitando o desenvolvimento da Agricultura e Silvicultura de Precisão. Estas técnicas envolvem o georreferenciamento de variáveis importantes para o processo de produção agrícola e florestal, possibilitando a elaboração de mapas detalhados de toda a área. Permitem, também, fazer o armazenamento, tratamento, análise e visualização espacial de todas as informações coletadas no campo, auxiliando o agricultor a tomar decisões com precisão. Além disso, as máquinas agrícolas (tratores, colhedoras etc.) equipadas com antenas GPS poderão fazer a aplicação localizada dos insumos agrícolas e fornecer dados que permitam o mapeamento da colheita no campo, identificando as áreas de maior ou menor produtividade.

A sua aplicação nas diferentes atividades agrícolas e florestais necessita ainda ter respondida uma série de indagações antes do seu uso generalizado, com o que se pretende contribuir por meio deste trabalho, cuja proposta principal foi a obtenção de informações operacionais sobre o uso de um receptor GPS da categoria submétrico em levantamentos topográficos, visando a sua aplicação no planejamento e execução dos mesmos. Particularmente no ramo florestal há uma forte demanda por serviços de posicionamento que não exigem a exatidão dos levantamentos topográficos convencionais, mas que se mostram mais úteis e valiosos a medida que se aumenta a rapidez com que podem ser obtidos.

Com a finalidade de se avaliar o efeito do dossel na recepção dos sinais GPS, foi testado neste trabalho o desempenho do receptor GPS Trimble/Pro-XL no levantamento de pontos localizados em áreas com diferentes coberturas vegetais (pastagem, seringueira, eucalipto e pinus), variando o tempo de permanência sobre estes pontos ( $1 \mathrm{~min}, 5 \mathrm{~min}$ e $10 \mathrm{~min}$ ), avaliando-se a exatidão do sistema e fornecendo dessa forma um subsídio para a sua utilização. 


\section{REVISÃO DE LITERATURA}

\subsection{O Sistema de Posicionamento Global (GPS)}

Segundo Leick (1990), Vettorazzi et al. (1994), Blitzkow (1995), van Sickle (1996), Segantine (1998) e Sá (2000), o sistema GPS (Global Positioning System) foi desenvolvido pelo U.S. Department of Defense (DoD) como um sistema de rastreio dos satélites NAVSTAR (Navigation System with Time and Ranging), que formam uma constelação, colocada em órbita da Terra para medição de distâncias entre esses satélites e estações localizadas na superfície terrestre e no espaço. O princípio básico de funcionamento usado no sistema GPS, consiste na transmissão de sinais eletrônicos pelos satélites, por meio de ondas eletromagnéticas, e na captação desses sinais por receptores, de tal forma que o intervalo de tempo decorrido no percurso possa ser determinado. Como a velocidade de propagação das ondas eletromagnéticas é conhecida (velocidade da luz), as distâncias entre os satélites e o receptor que os rastreia podem ser calculadas, o que permite determinar as coordenadas da posição onde foi estacionado o receptor. Assim, o GPS é um sistema espacial, desenvolvido originalmente para fins militares, que fornece ao usuário a posição espacial, a velocidade e o tempo decorrido num sistema de referência comum, a qualquer instante, em qualquer ponto da superfície terrestre, e independente das condições meteorológicas.

Apesar do sistema GPS ter sido desenvolvido e ser mantido pelo DoD com objetivos militares, o seu grande potencial para aplicações civis fez com que o Congresso Americano ordenasse ao DoD que promovesse o seu uso civil, que se iniciou em 1982 e desenvolveu-se rapidamente com aplicações do sistema em levantamentos geodésicos e sistemas de navegação. 
O sistema GPS é descrito por Leick (1990), Vettorazzi et al. (1994), Blitzkow (1995), van Sickle (1996), Segantine (1998) e Sá (2000), como sendo formado por uma constelação de 24 satélites distribuídos em 6 planos orbitais distintos, com inclinação de $55^{\circ}$ em relação ao equador e um período de 12 horas. Com esta configuração, em qualquer ponto da superfície terrestre ou próximo a ela haverá um mínimo de 4 satélites acima do horizonte 24 horas por dia (Figura 1).

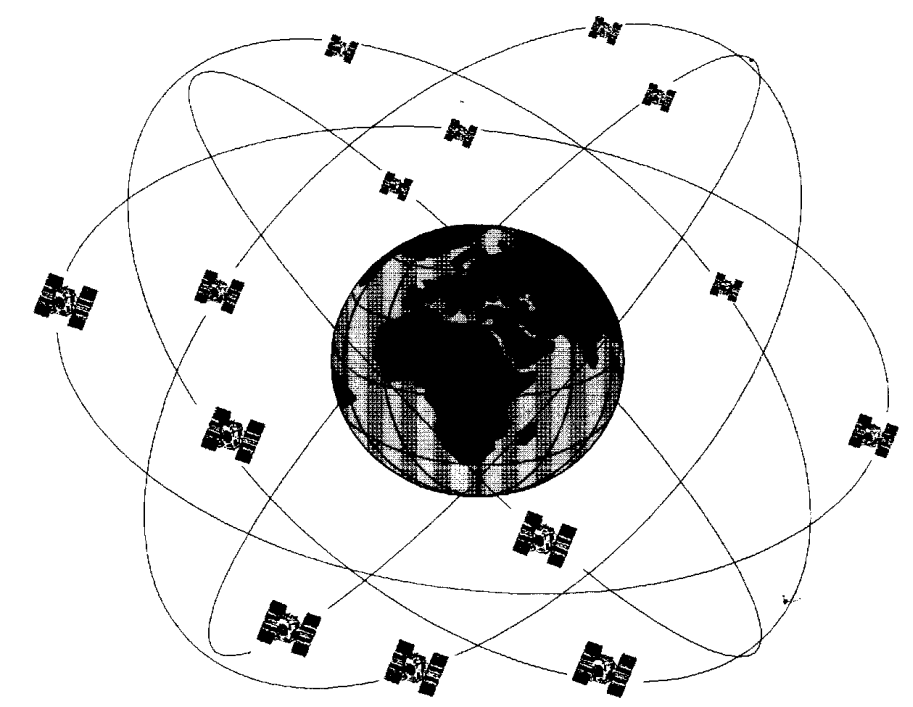

Figura 1 - Estrutura das órbitas dos satélites NAVSTAR/GPS. (Fonte: Blitzkow, 1995)

Os sinais emitidos pelos satélites são caracterizados por um certo número de componentes, todas baseadas numa frequência fundamental $\left(f_{0}\right)$ de $10,23 \mathrm{MHz}$, controlada por osciladores atômicos de césio. Assim, as ondas portadoras L1 e L2 são expressas a partir da frequência fundamental pelas relações:

$$
\begin{aligned}
& \mathrm{L} 1=154 \times f_{0}=1575,42 \mathrm{MHz}(\lambda=19,05 \mathrm{~cm}) \\
& \mathrm{L} 2=120 \times f_{0}=1227,60 \mathrm{MHz}(\lambda=24,45 \mathrm{~cm})
\end{aligned}
$$

Essas duas portadoras são moduladas em fase, por uma função degrau, com distinção entre as fases cossenoidal e senoidal.

A fase cossenoidal de ambas as portadoras (L1 e L2) é modulada por uma sequência de pulsos conhecida como código $\mathrm{P}$ (preciso ou protegido). O código P é gerado por um algorítmo que se repete a cada 267 dias. Esses 267 dias são divididos em 
38 segmentos de 7 dias. Cada satélite transmite um segmento específico de 7 dias do código $\mathrm{P}$, isto caracteriza cada satélite permitindo que se selecione um em particular para ser rastreado entre os que estão acima do horizonte.

Outro código semelhante ao $\mathrm{P}$, conhecido como código $\mathrm{Y}$, poderia ser utilizado, mas como sua equação é secreta e a do código $\mathrm{P}$ é de acesso público, os usuários não autorizados pelo DoD ficam restritos à utilização do código $\mathrm{P}$.

A fase senoidal da portadora L1 é modulada por uma sequência de pulsos chamada código C/A (clear / access ou coarse / acquisition). O código C/A é gerado pelo algoritmo de Gold em cada satélite, se repete a cada milisegundo e tem uma frequência de $1,023 \mathrm{MHz}$.

As duas portadoras (L1 e L2) contêm também, a mensagem transmitida pelo satélite, que consiste num fluxo de dados transmitidos em baixa frequência $(50 \mathrm{~Hz})$, informando o usuário sobre as condições operacionais e a posição de todos os satélites que compõem a constelação.

Com relação a disponibilidade seletiva (S/A), Bueno (2000) explica que se trata de uma técnica usada para degradar a exatidão de posicionamento geodésico, sendo o método de posicionamento absoluto, aquele em que se emprega somente um equipamento para a observação do código $\mathrm{C} / \mathrm{A}$, o mais afetado. Nesses casos essa degradação faz com que a latitude e a longitude sejam determinadas com erro de $100 \mathrm{~m}$ ou mais.

Ainda segundo Bueno (2000), no dia $1^{\underline{0}}$ de maio de 2000, por determinação do presidente Bill Clinton, a S/A foi desativada, contribuíram para essa decisão o programa de modernização do sistema GPS e o desejo de incentivar o uso do GPS para aplicações civis pacíficas.

Finalmente, pode-se concluir baseado nas observações de Kovach e van Dyke (1998) que a decisão presidencial de desativar a disponibilidade seletiva e a modernização e aperfeiçoamento no sistema GPS, bem como as melhorias esperadas nos 
receptores, permitirão uma significativa melhoria na exatidão de posicionamento e um futuro promissor para a utilização civil do sistema.

\subsection{Os receptores GPS}

Segundo Segantine (1998), os receptores GPS evoluíram muito desde os primeiros modelos lançados no mercado na década de 80 . Além disso, os métodos de posicionamento e a eletrônica dos componentes evoluíram bastante, resultando em equipamentos de diferentes exatidões para diferentes tipos de aplicações práticas.

Os receptores atuais podem operar tanto com o código como e/ou fase da portadora a um custo reduzido. Estes instrumentos podem ser utilizados em DGPS (correção diferencial) para navegação e também em alguns tipos de trabalhos topográficos.

Segantine (1998) também apresenta a seguinte classificação dos receptores GPS:

a) quanto ao número de frequências:

- simples frequência: equipamentos que recebem somente a frequência L1;

- dupla frequência: são aqueles que recebem as frequências L1 e L2, e que portanto permitem acesso aos códigos $\mathrm{C} / \mathrm{A}$ e ou $\mathrm{P}$.

b) quanto ao número de canais:

- monocanais: receptores que possuem apenas uma canal que se move rapidamente de um satélite para outro. Apesar de baratos têm a desvantagem de serem imprecisos e lentos no processamento das coordenadas;

- multicanais: estes equipamentos possuem vários canais independentes para rastrear, simultaneamente, cada satélite visível no horizonte. Isto proporciona um processamento mais rápido e preciso das coordenadas.

c) quanto ao tipo de canais: 
- sequenciais: nestes receptores cada canal rastreia um único satélite de cada vez, passando a captar dados de outro satélite tão logo tenha armazenado dados suficientes para o cálculo das coordenadas dos pontos;

- multiplexados: são instrumentos que têm o funcionamento semelhante aos anteriores, com a vantagem de serem mais rápidos na mudança para a captação de outros satélites.

d) quanto ao tipo de sinal observado:

- receptores que utilizam as pseudo distâncias por meio do código C/A: são os equipamentos normalmente utilizados na navegação marítima, aérea ou terrestre;

- receptores das portadoras L1 e L2 e do código C/A: são aqueles normalmente utilizados nos trabalhos geodésicos de precisão;

- receptores que utilizam as pseudo distâncias por meio do código P: são os receptores construídos para fins militares e, portanto, sob o controle do DoD;

- receptores que utilizam as pseudo distâncias por meio dos códigos C/A e P e utilizam as portadoras L1 e L2: a aplicação deste tipo de equipamento é justificada nos trabalhos geodésicos de alta precisão.

Sá (2000) também classifica os receptores GPS em 4 grupos em função do tipo de medida e da disponibilidade dos códigos:

a) receptores do código $\mathrm{C} / \mathrm{A}$ de pseudo distâncias: são equipamentos usados somente para medição de distâncias pelo código C/A. Geralmente são receptores portáteis que operam em movimento, alimentados por pilhas comuns, que possuem até 6 canais independentes e fornecem a posição em termos de coordenadas geodésicas e, eventualmente, em termos de coordenadas planas da projeção UTM;

b) receptores do código $\mathrm{C} / \mathrm{A}$ de fase da portadora: com este tipo de receptor, somente pseudo distâncias e fase da portadora L1 podem ser obtidas porque o código não é modulado na L2. Portanto não fornece dados em duas frequências. A maioria dos equipamentos possuem no mínimo 4 e no máximo 12 canais independentes. Esses instrumentos desempenham todas as funções dos modelos previamente descritos, 
além de armazenar o tempo decorrido e a fase da portadora em algum tipo de memória;

c) receptores do código P: esse tipo de equipamento proporciona o rastreio das portadoras L1 e L2. Os códigos P dessas portadoras são obtidos pela correlação dos sinais transmitidos pelos satélites, com as réplicas dos códigos $\mathrm{P}$ gerados no receptor. Para isso, a estrutura do sinal deve ser conhecida. Os receptores do código P têm a vantagem de medir distâncias com a exatidão de alguns centímetros, com apenas 10 minutos de rastreio;

d) receptores do código $\mathrm{Y}$ : receptores desse tipo permitiam acesso ao código $\mathrm{P}$ com a SA ativada. Logo, os códigos de distância e fases podem ser determinados a partir das portadoras L1 e L2 pela técnica de correlação do código P. O acesso ao código $\mathrm{P}$ é possível com a instalação de um Auxiliary Output Chip (AOC) em cada canal do receptor. Esse "chip" proporciona a decodificação do código Y em P e a degradação decorrente da SA. Entretanto, somente usuários autorizados pelo DoD tem acesso ao AOC.

Ainda com relação à classificação de receptores GPS, Vettorazzi et al. (1994) mencionam o alto potencial de uso do GPS nas atividades agrárias, em especial no Brasil. Descrevem uma classificação da exatidão obtida com a tecnologia GPS, conforme exposto na Tabela 1, citando que para grande parte das atividades com potencialidade de emprego do GPS nas áreas agrícola e florestal, equipamentos pertencentes à categoria $\mathrm{B}$ poderão ser empregados satisfatoriamente.

Tabela 1. Classificação dos receptores GPS de acordo com sua exatidão.

\begin{tabular}{ccccc}
\hline Categoria & $\begin{array}{c}\text { Número de } \\
\text { receptores }\end{array}$ & $\begin{array}{c}\text { Tempo de } \\
\text { leitura }\end{array}$ & Sinais utilizados & Exatidão \\
\hline $\mathrm{A}$ & 1 & Instantânea & $\mathrm{C} / \mathrm{A}$ & $100 \mathrm{~m} * *$ \\
$\mathrm{~B}$ & 2 & $1-2$ min. & $\mathrm{C} / \mathrm{A}$ & $1 \mathrm{~m}-5 \mathrm{~m}$ \\
$\mathrm{C}$ & 2 & 1 hora & C/A-L1 & $1 \mathrm{~cm} \pm 2 \mathrm{ppm}$ \\
$\mathrm{D}$ & 2 & 1 hora & C/A-P-L1-L2 & $0,5 \mathrm{~cm} \pm 1 \mathrm{ppm}$ \\
\hline
\end{tabular}

** Nesta época a SA ainda estava operacional.

Fonte: Vettorazzi et al. (1994) 
Confirmando a importância do tipo de receptor utilizado em levantamentos GPS, Segantine (1998) explica que o tipo de dado coletado pelo receptor tem um impacto direto na exatidão alcançada, e, geralmente, influencia no custo final da operação. Assim os receptores mais baratos disponíveis no mercado são aqueles que fornecem o posicionamento em tempo real, baseado somente no código $\mathrm{C} / \mathrm{A}$ com exatidão da ordem de $100 \mathrm{~m}$ na horizontal e $150 \mathrm{~m}$ na vertical quando a SA estava em funcionamento. Receptores com código $\mathrm{P}$, são similares em operação mas ofereciam uma exatidão de $25 \mathrm{~m}$ na horizontal e $30 \mathrm{~m}$ na vertical (S/A em funcionamento), mas está restrito ao uso militar. Por outro lado equipamentos que operam com a observação da fase da portadora, em vez da pseudo distância, são mais exatos.

Hoje, com a S/A desativada espera-se que a exatidão de posicionamento, no método absoluto, melhore em até 10 vezes segundo Benevento (2000). O autor informa também que, nas determinações em que se aplica a correção diferencial (DGPS) a exatidão não deve ser afetada, pois o erro devido a S/A já é praticamente totalmente retirado no processo de correção.

\subsection{Métodos de posicionamento com GPS}

Para Bueno (1995), existem diversos métodos de utilização do sistema GPS, a todos têm por princípio a medida da distância entre o satélite e o receptor. Ainda segundo o autor as classificações dos métodos de posicionamento podem seguir diversos critérios:

1. tendo em conta a existência ou não de um ponto com coordenadas conhecidas para ser utilizado como referência:

- $\quad$ sem ponto de referência = absoluto;

- $\quad$ com ponto de referência $=$ relativo.

2. tendo em conta o tipo de observação:

- distância obtida pelo código;

- distância obtida pela portadora; 
- distância obtida pela combinação de ambas.

3. considerando o tempo empregado na observação:

- longo tempo de observação;

- curto tempo de observação;

- em tempo real.

Ainda segundo Bueno (1995), os métodos de posicionamento diferencial estático são os mais precisos dentre os que utilizam a tecnologia GPS, e podem ser subdivididos em 5 variantes: base simples; solução em rede; solução com relaxação orbital; pseudo cinemático; e rápido-estático.

Sá (2000) aborda os principais tipos de posicionamento de maneira semelhante a Bueno (1995) e afirma que os problemas de posicionamento que geralmente aparecem na prática podem ser classificados, quanto ao referencial e número de pontos envolvidos em:

1. absoluto: determinação das coordenadas de pontos diretamente associadas a um referencial e usando um receptor;

2. relativo: determinação das diferenças de coordenadas entre 2 pontos e utilizando 2 receptores;

3. forma de rede: determinação das coordenadas de um conjunto de pontos, usando mais de 2 receptores.

Ainda segundo Sá (2000), o posicionamento GPS baseia-se principalmente na medição do código ou da fase da portadora e apresenta essas informações nas Tabelas 2 e 3. 
Tabela 2. Técnicas de posicionamento por meio da portadora e SA em funcionamento

\begin{tabular}{|c|c|c|c|c|c|}
\hline Método & $\begin{array}{l}\text { Conceitos } \\
\text { básicos }\end{array}$ & $\begin{array}{c}\mathrm{N}^{\mathbf{0}} \text {. min. } \\
\text { Receptores }\end{array}$ & $\begin{array}{c}\text { Tempo } \\
\text { de } \\
\text { observ. }\end{array}$ & Exatidão & Comentário \\
\hline Estático & $\begin{array}{c}\text { Rastreio } \\
\text { simultâneo } \\
\text { (base e móvel) }\end{array}$ & 2 & 1 hora & $\begin{array}{l}1 \mathrm{~cm}+(1- \\
10) \mathrm{ppm}\end{array}$ & $\begin{array}{c}\text { Complexidade } \\
\text { variável }\end{array}$ \\
\hline $\begin{array}{l}\text { Cinemático } \\
\text { (Fase da } \\
\text { portadora) }\end{array}$ & $\begin{array}{l}\text { O receptor móvel } \\
\text { é posicionado em } \\
\text { relação à base } \\
\text { durante } \\
\text { movimento } \\
\end{array}$ & 2 & - & $0,1-1 \mathrm{~m}$ & $\begin{array}{c}\text { Requer } \\
\text { rastreio } \\
\text { contínuo } \\
\text { durante todo o } \\
\text { movimento } \\
\end{array}$ \\
\hline $\begin{array}{c}\text { Semi } \\
\text { cinemático } \\
(S t o p \& G o)\end{array}$ & $\begin{array}{l}\text { O receptor móvel } \\
\text { é posicionado em } \\
\text { relação à base } \\
\text { com uma } \\
\text { pequena parada } \\
\text { nos pontos } \\
\end{array}$ & 2 & $\begin{array}{l}\text { Cerca de } \\
1 \text { minuto } \\
\text { por ponto }\end{array}$ & $\begin{array}{c}\text { Alguns } \\
\text { centímetros }\end{array}$ & $\begin{array}{l}\text { Limitado a } \\
\text { bases com } \\
\text { cerca de } \\
\text { 20km, rastreio } \\
\text { e contínuo }\end{array}$ \\
\hline $\begin{array}{c}\text { Pseudo } \\
\text { cinemático }\end{array}$ & $\begin{array}{l}\text { O receptor móvel } \\
\text { ocupa duas vezes } \\
\text { (com intervalos } \\
\text { de uma hora) } \\
\text { para explorar a } \\
\text { variação da } \\
\text { geometria dos } \\
\text { satélites } \\
\end{array}$ & 2 & $\begin{array}{l}\text { De 1-3 } \\
\text { minutos }\end{array}$ & $\begin{array}{l}\text { Algumas } \\
\text { ppm }\end{array}$ & $\begin{array}{l}\text { Ocupação } \\
\text { dupla, } \\
\text { problemas } \\
\text { logísticos }\end{array}$ \\
\hline $\begin{array}{l}\text { Estático } \\
\text { rápido }\end{array}$ & $\begin{array}{l}\text { Usa técnicas } \\
\text { sofisticadas e } \\
\text { informações } \\
\text { extras para } \\
\text { resolver a } \\
\text { ambigüidade }\end{array}$ & 2 & $\begin{array}{l}\text { De 3-5 } \\
\text { minutos }\end{array}$ & $\begin{array}{c}\text { Alguns } \\
\text { centímetros }\end{array}$ & $\begin{array}{l}\text { Para bases de } \\
20 \mathrm{~km}, \\
\text { geralmente } \\
\text { requer } \\
\text { medidas } \\
\text { extras } \\
\end{array}$ \\
\hline
\end{tabular}

Fonte: Sá (2000)

A precisão e a exatidão dos métodos de posicionamento são outros aspectos que devem ser considerados. Assim August et al. (1994) avaliaram a precisão e a exatidão do GPS com e sem correção diferencial, confirmando a eficiência desta sobre a distorção provocada pela Disponibilidade Seletiva (SA). Determinaram como a exatidão se comporta, estando o aparelho estacionado em um ponto, a medida que cresce o número de dados coletados em um período de tempo, até um máximo de 300 leituras. 
Tabela 3. Técnicas de posicionamento por meio do código C/A e SA em funcionamento

\begin{tabular}{|c|c|c|c|c|c|}
\hline Método & $\begin{array}{c}\text { Conceitos } \\
\text { básicos } \\
\end{array}$ & $\begin{array}{l}\mathrm{N}^{0} . \min . \\
\text { recep. }\end{array}$ & $\begin{array}{l}\text { Tempo de } \\
\text { observ. }\end{array}$ & Exatidão & Comentário \\
\hline Absoluto & Requer 4 satélites & & & $100 \mathrm{~m}$ & \\
\hline $\begin{array}{l}\text { Estático ou } \\
\text { cinemático }\end{array}$ & $\begin{array}{l}\text { Posicionamento } \\
\text { instantâneo }\end{array}$ & 1 & $1-10 s$ & $\begin{array}{c}\text { (horizontal) } \\
200 \mathrm{~m} \\
\text { (vertical) }\end{array}$ & $\begin{array}{l}\text { simples e } \\
\text { barato }\end{array}$ \\
\hline $\begin{array}{l}\text { Relativo } \\
\text { Estático ou } \\
\text { cinemático }\end{array}$ & $\begin{array}{c}\text { Requer } 4 \text { satélites } \\
\text { Usa correções } \\
\text { determinadas na } \\
\text { base }\end{array}$ & 2 & $1-50 s$ & $\begin{array}{c}2-3 \mathrm{~m} \\
\text { (horizontal e } \\
\text { vertical) }\end{array}$ & $\begin{array}{l}\text { É simples e } \\
\text { barato }\end{array}$ \\
\hline
\end{tabular}

Fonte: Sá (2000)

Observaram que menos de 20 repetições por ponto melhoram muito pouco a exatidão, enquanto 50 repetições ou mais melhoram marcadamente tanto a exatidão quanto a precisão. Ressalta-se que os resultados foram obtidos em condições extremamente favoráveis de levantamento, sendo que dados obtidos sob condições mais adversas, como por exemplo geometria pobre dos satélites e obstruções entre o receptor e o satélite, são provavelmente menos precisos.

Em sua descrição do sistema GPS, o IBGE (1994) relata a necessidade de intervisibilidade entre a estação e o satélite. Uma vez que os sinais transmitidos podem ser absorvidos, refletidos ou refratados por objetos próximos à antena ou entre a antena e o satélite, recomenda que o horizonte em torno da antena esteja desobstruído acima de 15 graus. Deve-se evitar locais próximos a estações de transmissão de microondas, radares, antenas rádio-repetidoras e linhas de transmissão de alta voltagem, por representarem fontes de interferência para os sinais GPS. O efeito de retardo do sinal causado pela sua reflexão é chamado de multicaminhamento (multipath) e a fim de minimizar esse problema, a área situada a 50 metros da estação deve estar livre de estruturas artificiais, particularmente paredes e cercas metálicas. Esse efeito é função da geometria da configuração dos satélites observados, que por sua vez se modifica com o tempo. Referindo-se a posicionamentos estáticos, ressalta que, desta forma, quanto maior o período de observação, maior a probabilidade de redução dos efeitos do multicaminhamento. Quanto à escolha da taxa de observação (intervalo de tempo entre a 
gravação de observações consecutivas), esta depende da técnica de posicionamento utilizada no levantamento. A regra geral é que quanto maior a taxa de observação, mais fácil é a detecção e a correção da perda de ciclos. Por outro lado, uma taxa alta gera arquivos de observação muito grandes, dificultando sua manipulação. De uma maneira geral, para posicionamentos estáticos, a taxa de uma observação a cada 15 segundos tem se mostrado adequada. Para posicionamentos cinemáticos, uma taxa mais alta pode se necessária.

Ainda com relação as exatidões possíveis de serem alcançadas pelos métodos cinemático e estático de levantamentos GPS, Segantine (1998) apresenta as tabelas 4 e 5 .

Tabela 4. Exatidões do método cinemático

\begin{tabular}{ccccc}
\hline Freqüência & Base (km) & Satélites & $\begin{array}{c}\text { Tempo de } \\
\text { observação (min) }\end{array}$ & $\begin{array}{c}\text { Exatidão } \\
\text { (ppm) }\end{array}$ \\
\hline Simples & 3 & 5 & 0,1 & 10 \\
\hline $\begin{array}{c}\text { Dupla } \\
\text { (código P) }\end{array}$ & 3 & 5 & 3 & 3 \\
\hline
\end{tabular}

Fonte: Segantine (1998)

Tabela 5. Exatidões do método estático

\begin{tabular}{ccccc}
\hline Freqüência & Base $\mathbf{( k m )}$ & Satélites & $\begin{array}{c}\text { Tempo de } \\
\text { observação (min) }\end{array}$ & $\begin{array}{c}\text { Exatidão } \\
\text { (ppm) }\end{array}$ \\
\hline & 1 & 4 & 30 & $5-10$ \\
Simples & 5 & 5 & 15 & 5 \\
& 10 & 5 & 60 & 4 \\
& 30 & 4 & 30 & 3 \\
& 5 & 4 & 60 & 0,1 \\
(sem código) & 100 & 5 & 120 & 1 \\
Dupla & 50 & 5 & 90 & 0,1 \\
(código P) & 100 & 4 & 120 & $0,1-0,01$ \\
\hline
\end{tabular}

Fonte: Segantine (1998) 


\subsection{Aplicações nas áreas agrícola e florestal.}

Vários autores têm relatado a aplicação do sistema GPS em atividades relacionadas com às áreas agrícola e florestal.

Bergstrom (1990) relata sua experiência com GPS no levantamento de uma área florestal e na localização de árvores mortas para aproveitamento, tendo obtido resultados satisfatórios em ambos. Especificamente no levantamento, a mesma área também foi medida por meio do uso de trena, clinômetro e bússola, gastando aproximadamente dez vezes mais homens-hora nesse trabalho. Os levantamentos foram executados com GPS autônomo em época em que a disponibilidade seletiva (SA) ainda não estava sendo aplicada.

Long et al. (1992) testaram o uso de GPS em levantamento de solo, comparando as coordenadas reais dos pontos de amostragem com as obtidas com um receptor GPS e concluíram que esta metodologia foi suficientemente exata para o posicionamento e navegação no campo, bem como a determinação dos limites entre os diferentes tipos de solo. Observaram também uma grande eficiência nos trabalhos de campo quando comparados com as metodologias convencionais.

Greer (1993), comentando a importância da localização precisa dos recursos naturais, mostra a conveniência da integração entre GPS, SIG e sensoriamento remoto. Descreve a importância do GPS no fornecimento ininterrupto de informações, a um custo menor do que com os levantamentos convencionais. Descreve o SIG como um mapa eletrônico que armazena tanto dados de localização como informações descritivas de uma área, permitindo a comparação de diversos planos de informação, apresentandoos na forma gráfica.

De acordo com Kruczinsky \& Jasumback (1993), características do GPS como alcance global, acesso ao sistema pelo público, imunidade à saturação e insensibilidade ao tempo são elementos decisivos na confiabilidade do sistema. A imunidade à saturação refere-se ao fato de que, sendo o sistema passivo - os usuários somente recebem os sinais - não possa ser saturado pelo excesso de usuários. Relatam 
que o Serviço Florestal americano identificou mais de 130 aplicações possíveis em sua investigação sobre GPS. Dificuldades de bloqueio de sinal, tamanho, peso e custo do equipamento limitam seu uso, mas essas restrições devem rapidamente desaparecer com o avanço da tecnologia. No levantamento de uma área em que foi comparado o desempenho do GPS com o uso da topografia convencional, mencionam que enquanto para esta última obteve-se uma área de 328,36 acres, com o GPS sem correção diferencial obteve-se 330,00 acres, correspondendo a uma diferença de 0,5\%. Medindose a mesma área com correção diferencial chegou-se a 328,16 acres (uma diferença de 0,2 acre correspondente a $0,06 \%$ ). Comentam, também, que é esperada grande expansão na utilização de receptores GPS em aplicações aéreas, tomando como exemplo dois programas que o Serviço Florestal americano desenvolve no combate a incêndios. No primeiro programa, são detectados por via aérea os focos de incêndio, cuja posição demarcada pelo GPS é transmitida para o pessoal da terra. Neste caso é necessário o GPS diferencial em tempo real. No segundo programa, uma aeronave provida de receptor, geralmente um helicóptero, contorna o perímetro da área incendiada que, após o pouso, é então plotada. Neste caso é aceitável o uso do GPS diferencial pós processado. Mencionam as vantagens da utilização destes equipamentos para inventários e demarcações florestais, estando entre os benefícios dessas informações o uso mais eficiente dos recursos florestais e os ganhos decorrentes de melhores inventários.

Segundo August et al. (1994), especialistas na área ambiental, têm-se utilizado do sistema GPS para o posicionamento das feições levantadas no campo. A exatidão obtida com um equipamento de baixo custo, testado pelos autores, depende da metodologia empregada no levantamento. Sob condições ideais de operação, 95\% dos pontos foram localizados dentro de uma raio de $73 \mathrm{~m}$ quando não se procedeu a correção diferencial, e em um raio de $6 \mathrm{~m}$ quando a correção diferencial foi realizada.

Em dois trabalhos realizados na região do Pantanal Brasileiro, por Silva et al. (1998) e Silva \& Abdon (1998), o primeiro no levantamento de desmatamento do Pantanal em 1990/1991 e o segundo feito para a delimitação do Pantanal e suas sub- 
regiões, um receptor GPS foi utilizado para a checagem de campo e integração destes dados com um sistema de informações geográficas.

Nesta mesma linha de trabalho, McCormick (1999) conduziu um estudo detalhado da vegetação em "East Everglades", nos EUA, para mapear a distribuição de Malaleuca quenervia, uma espécie vegetal exótica e agressiva, marcada para erradicação. Neste mapeamento foi feita a integração entre fotografias aéreas infravermelho, sistema de informação geográfica e GPS para produção de mapas na escala 1:5000. O autor conseguiu obter uma exatidão de $94 \%$ no mapeamento, o que permitiu um manejo adequado desta espécie vegetal.

A mais recente aplicação, na área agrícola, do sistema GPS encontra-se na agricultura de precisão. Segundo Stafford (1999), o advento desta nova tecnologia está abrindo um grande mercado potencial para utilização do sistema GPS.

Dentro desta linha de trabalho, o sistema GPS foi testado por Webster \& Cardina (1997) para o mapeamento de ervas daninhas. O experimento foi conduzido para testar a exatidão do GPS em delimitar manchas de ervas daninhas no campo. Para isso foram marcadas áreas de $5,0 \mathrm{~m}^{2}, 50,0 \mathrm{~m}^{2}$ e $500,0 \mathrm{~m}^{2}$ que foram medidas com o equipamento, os valores obtidos, quando comparados com a medida real, mostraram uma variação de $7 \%$ a $45 \%, 6 \%$ a $15 \%$ e $3 \%$ a $6 \%$ respectivamente, ou seja, com o aumento das áreas das manchas os erros diminuíram.

Em outro trabalho, Al-Gaadi \& Ayers (1999), avaliaram a integração entre GPS e SIG na determinação da variabilidade espacial de um sistema de aplicação de herbicida e concluíram que a utilização da correção diferencial (DGPS) permitiu uma exatidão no posicionamento da aplicação de pelo menos 1,0m.

Ainda com relação à agricultura de precisão, Balastreire et al. (1997) executaram, com boa exatidão, o mapeamento da produtividade do milho em uma área de 7,0ha, utilizando na colhedora um receptor GPS da marca Trimble modelo PRO-XL, com posicionamento pelo método de correção diferencial (DGPS) pós-processada e registro das informações. Nesta mesma linha de trabalho, Drummond et al. (1999) 
relatam que utilizaram o método de posicionamento GPS cinemático em tempo real, para o levantamento da área colhida por unidade de tempo (cultura da soja) e que, com estes dados, geraram um mapa de produtividade da área plantada.

Além das aplicações acima citadas deve-se também registrar o trabalho de Turner et al. (2000), que realizaram o monitoramento do comportamento de gado de corte na pastagem, onde os animais utilizavam um colar com receptor GPS. Com as informações obtidas os autores puderam implementar pesquisa sobre o melhor manejo para estes animais.

\subsection{Influência da cobertura vegetal e de outros fatores no desempenho do sistema GPS.}

$\mathrm{Na}$ avaliação do desempenho do GPS com e sem cobertura florestal, Gerlach (1989) obteve resultados mais precisos na área sem cobertura. Detectou uma significativa redução na eficiência do receptor devido à obstrução pelo relevo e objetos na paisagem como troncos, galhos e folhagens. Ressalva que a precisão obtida sob as copas das árvores foi condizente com as necessidades das operações florestais usuais. Observa também que o modo diferencial pós-processado geralmente produz resultados melhores do que o modo autônomo.

Petersen (1990) descreve avaliações do GPS sob diferentes condições de terreno e de coberturas florestais, comentando que, apesar dos avanços na tecnologia de recepção de sinais, os problemas decorrentes de sua atenuação pela cobertura vegetal continuam presentes. Posições que podem ser obtidas em um ou dois minutos em áreas abertas podem requerer uma hora ou mais para a determinação em uma área de mata. Não acredita que a cobertura florestal impeça o uso do GPS, mas afirma que nessa situação a sua capacidade fica restringida.

Evans et al. (1992) mencionam que a cobertura vegetal de florestas pode atenuar os sinais dos satélites GPS, degradando a capacidade de fixação da posição pelos receptores. A cobertura vegetal é significante na redução do número e da qualidade das 
observações, tendo os autores encontrado, além da perda da "visibilidade" do satélite, problemas com a portabilidade dos aparelhos e influência do operador. Relatam também as dificuldades encontradas na localização de parcelas dentro de áreas florestais, pelos meios convencionais de levantamento, e que o sistema GPS pode fornecer para essas necessidades uma alternativa de localização precisa e mais rápida. Observam que a experiência pessoal do operador com os métodos convencionais de demarcação de parcelas pode diminuir o rendimento do trabalho no uso deste equipamento porque os operadores têm a tendência de buscar auxílio nos seus conhecimentos do sistema convencional de localização e medição, adquiridos na experiência de campo, o que só acaba prejudicando o aproveitamento do trabalho com GPS.

Lance (1993) comenta que, apesar da tecnologia GPS poder reduzir substancialmente o trabalho e custos em atividades florestais, ela não é apropriada para todas as aplicações nesse ramo. Menciona que o avanço dos componentes eletrônicos vem aumentando a precisão dos receptores. Quanto à obtenção da precisão submétrica, ela demanda um tempo de locação que pode tornar-se impeditivo ao seu uso em aplicações florestais. Descreve a influência da cobertura florestal na recepção do sinal GPS, acarretando o seu bloqueio e degradação da exatidão. A respeito do efeito da umidade das folhas das árvores na recepção do sinal, menciona que algumas opiniões apontam que espécies florestais com folhas de menor umidade afetam menos o sinal, como é o caso do eucalipto. Relata também resultados mais bem sucedidos sob coníferas do que em árvores de folhas largas. Finalmente, observa que os receptores multicanais com recepção contínua podem calcular posições mais rápido, mais precisamente e com menor perturbação pelas copas das árvores.

Conforme Sumpter (1993), o GPS permite exatidões acima de 1:100.000 em ambientes florestais e acima de 1:1.000.000 em ambientes não-florestais. Menciona que os levantamentos podem ser estático, cinemático, estático-rápido, cinemático em tempo real e diferencial em tempo real. Para obter levantamentos mais eficientes, o GPS é integrado com técnicas que adotam equipamentos convencionais de levantamento como estações totais e instrumentos de medição eletrônica. Métodos de levantamento 
estático são usados em levantamentos geodésicos e na aferição de linhas de divisa. $\mathrm{O}$ tempo de ocupação por ponto varia com o comprimento da linha base e com a cobertura vegetal. Os métodos de levantamento estático permitem as maiores exatidões, sendo que os métodos de levantamento cinemático são apropriados onde as copas das árvores não estão presentes e os receptores podem acessar os satélites continuamente. Utilizações típicas incluem a subdivisão de áreas, levantamento de talhões, parcelas e sítios, demarcação de pontos e levantamentos de controle. $\mathrm{O}$ tempo de estacionamento por posição pode ser de dois minutos ou menos e a exatidão horizontal de $2 \mathrm{~cm}$ ou menos. $\mathrm{O}$ método de levantamento estático-rápido é utilizado para linhas de divisa e controle fotogramétrico, produzindo uma exatidão horizontal de $2 \mathrm{~cm}$. É a técnica mais rápida que não requer que o receptor esteja continuamente conectado ao satélite.

Rempel et al. (1995), avaliando um sistema automático de localização de animais baseado em GPS, no Canadá, verificaram que características de dossel (cobertura florestal) influenciaram a exatidão de posicionamento e a taxa de observação.

Liu \& Brantigan (1995) testaram a exatidão e a eficiência do método diferencial de posicionamento (DGPS) em ambientes florestais e chegaram às seguintes conclusões: 1) que a cobertura vegetal e a ondulação do terreno em regiões montanhosas influenciaram na exatidão do posicionamento DGPS; 2) de maneira geral, os resultados obtidos no levantamento estático/DGPS foram mais exatos, mas o trabalho de campo foi menos produtivo quando comparado com os resultados obtidos no levantamento cinemático/DGPS; e 3) resultados com baixa exatidão foram obtidos tanto quando foi utilizado o método estático quanto o método cinemático de posicionamento DGPS.

Deckert \& Bolstad (1996) estudaram o desempenho de um equipamento GPS Trimble Pathfinder Professional sob diferentes condições de cobertura florestal e também de relevo, na região leste dos EUA. Suas principais conclusões foram que a interferência do dossel e do terreno ( tipo de relevo ) reduzem a exatidão e a eficiência do sistema, porque a geometria ótima de satélites no espaço pode não ser visível, mesmo estando acima do horizonte. PDOP alto causando exatidões menores. 
Segundo Pessoa (1997), o GPS vem se consolidando como sistema padrão para georreferenciamento em todo o mundo. Entretanto, para melhor aproveitamento é importante conhecer suas principais limitações:

a) geometria da constelação de satélites: de uma maneira geral, o DOP (Dilution of Precision) quantifica a influência da geometria instantânea do conjunto de satélites acima do horizonte. O DOP pode ser dividido em PDOP, HDOP, VDOP e TDOP, responsáveis respectivamente pelas precisões do posicionamento tridimensional, horizontal, vertical e da determinação do tempo. Desse modo, no posicionamento instantâneo com um único rastreador, a exatidão obtida será tanto pior quanto maior for o valor do DOP no instante da determinação;

b) atmosfera: os efeitos atmosféricos sobre o GPS são devidos principalmente às influências da ionosfera e da troposfera. O reflexo do efeito ionosférico pode variar de $1 \mathrm{~m}$ a $100 \mathrm{~m}$ e é uma função da posição, tempo e frequência utilizada. O efeito da ionosfera pode ser eliminado pela combinação das frequências L1 e L2. Por essa razão, para aplicações de alta precisão ou no rastreamento relativo de bases longas, instrumentos de duas frequências devem ser utilizados. Já o efeito da troposfera independe da frequência utilizada e não é correlacionado com a distância entre estações. Por esse motivo, o atraso gerado pela refração troposférica nos sinais rastreados é critico para as determinações GPS, notadamente em relação à altimetria. A correção deste efeito no sinal GPS é efetuada por meio da utilização de modelos teóricos da troposfera e é mais significativo em aplicações geodésicas com utilização das frequências portadoras que na navegação;

c) multicaminhamento: outra fonte de distorções sobre o sinal transmitido é o efeito do multicaminhamento, resultado da reflexão indesejada do sinal por obstáculos próximos à antena receptora, podendo afetar tanto a propagação de códigos quanto portadoras, sendo duas vezes maior no código P que na portadora.

Para Gilbert (1997a), o multicaminhamento é provavelmente uma das mais frequentes fontes de erro GPS. Esses erros ocorrem quando o receptor recebe um sinal refletido somado ao sinal original que percorre um caminho direto para a antena 
GPS. Essa interferência pode resultar em degradação da posição, que varia desde um erro de alguns metros até dezenas de metros. Isso ocorre quando o receptor itinerante é carregado em uma área onde os sinais de multicaminhamento são presentes, recebendo assim sinais errados que a estação base não recebe. Como esses erros não são comuns a ambos receptores, não são removidos por correção diferencial. Os diferentes receptores GPS variam muito quanto a sua resistência em aceitar os sinais de multicaminhamento.

Ainda segundo Gilbert (1997b), os fatores mais importantes que determinam o sucesso de obtenção de valores posicionais com o GPS, sob condições de cobertura vegetal, podem ser enquadrados em três grandes categorias: 1) o ambiente; 2) as técnicas de coleta de dados; e 3) o equipamento GPS. Os principais fatores ambientais são as características da própria cobertura, como o tipo e espessura. Quanto à técnica de coleta de dados, os resultados podem ser diferentes quando se coletam dados do modo estático ou em movimento. As técnicas de processamento de sinais empregadas também têm impacto sobre os resultados. O receptor e a antena desempenham um papel importante no sucesso do trabalho sob condições de cobertura.

Naesset (1999), utilizando receptores GPS de 6 e 12 canais que captavam os sinais do código C/A e das portadoras, avaliou a exatidão de posicionamento de pontos levantados por estes equipamentos operando sob duas condições de cobertura vegetal: 1) coníferas; e 2) árvores com folhas decíduas. A exatidão foi determinada para 38 posições utilizando o processamento diferencial dos dados, com a recepção só do código C/A e combinação deste código com as portadoras, sendo que os tempos de observação variaram entre 2,5 e 30 minutos. Os resultados obtidos mostraram que: a) com o receptor de 12 canais foi possível obter uma maior exatidão no posicionamento, que com o receptor de 6 canais, para todas as condições de trabalho; b) a combinação da observação do código C/A e portadora melhorou a exatidão de posicionamento para os dois tipos de equipamentos ; e c) a exatidão melhorou com a com a melhor distribuição geométrica dos satélites (DOP).

Sigrist et al. (1999) também testaram o impacto de diferentes tipos e densidades de cobertura florestal na coleta de dados, exatidão e precisão de 
posicionamento GPS. Concluíram que a relação entre a densidade de cobertura florestal e exatidão têm um padrão exponencial, onde pequenos aumentos na densidade de cobertura acarretam grandes erros de posicionamento. Sugerem, em seu trabalho, que para a diminuição desses erros deve-se obter pelo menos 300 registros de posicionamento por ponto levantado e que o PDOP não é um bom indicador de exatidão de posicionamento quando se trabalham sob florestas.

Finalmente, Naesset et al. (2000) operando com um receptor de 24 canais que recebia sinais do código C/A e das portadoras do sistema GPS e GLONASS, concluíram que a exatidão no posicionamento aumentou com a diminuição da densidade de cobertura da floresta e com a melhora na distribuição geométrica dos satélites observados. 


\section{MATERIAL E MÉTODOS}

\subsection{Material}

3.1.1. Localização da área de estudo

A área de estudo encontra-se no Campus "Luiz de Queiroz" da Universidade de São Paulo, no município de Piracicaba, Estado de São Paulo, cujas coordenadas aproximadas são: a) latitude de $22^{\circ} 42^{\prime} 40^{\prime \prime} \mathrm{S}$ e b) longitude de $47^{\circ} 37^{\prime} 30^{\prime \prime}$ WG. A altitude varia entre $500 \mathrm{~m}$ e $600 \mathrm{~m}$, com o relevo variando de suave ondulado a ondulado.

\subsubsection{Equipamentos}

\subsubsection{Distanciômetro eletrônico}

Foi utilizado no levantamento topográfico dos pontos um medidor eletrônico de distâncias PENTAX / PX-06D, que possui uma luneta com aproximação de $30 \mathrm{X}$, círculos vertical e horizontal graduados em graus, com leitura digital de 6" e medidor eletrônico de distância (infravermelho) com alcance de 2,0km em condições atmosféricas normais e operando com 3 prismas, com uma exatidão de $\pm 5 \mathrm{~mm}+5 \mathrm{ppm}$.

\subsubsection{Equipamentos GPS}

O receptor GPS utilizado foi o modelo Pathfinder Pro XL, fabricado pela 


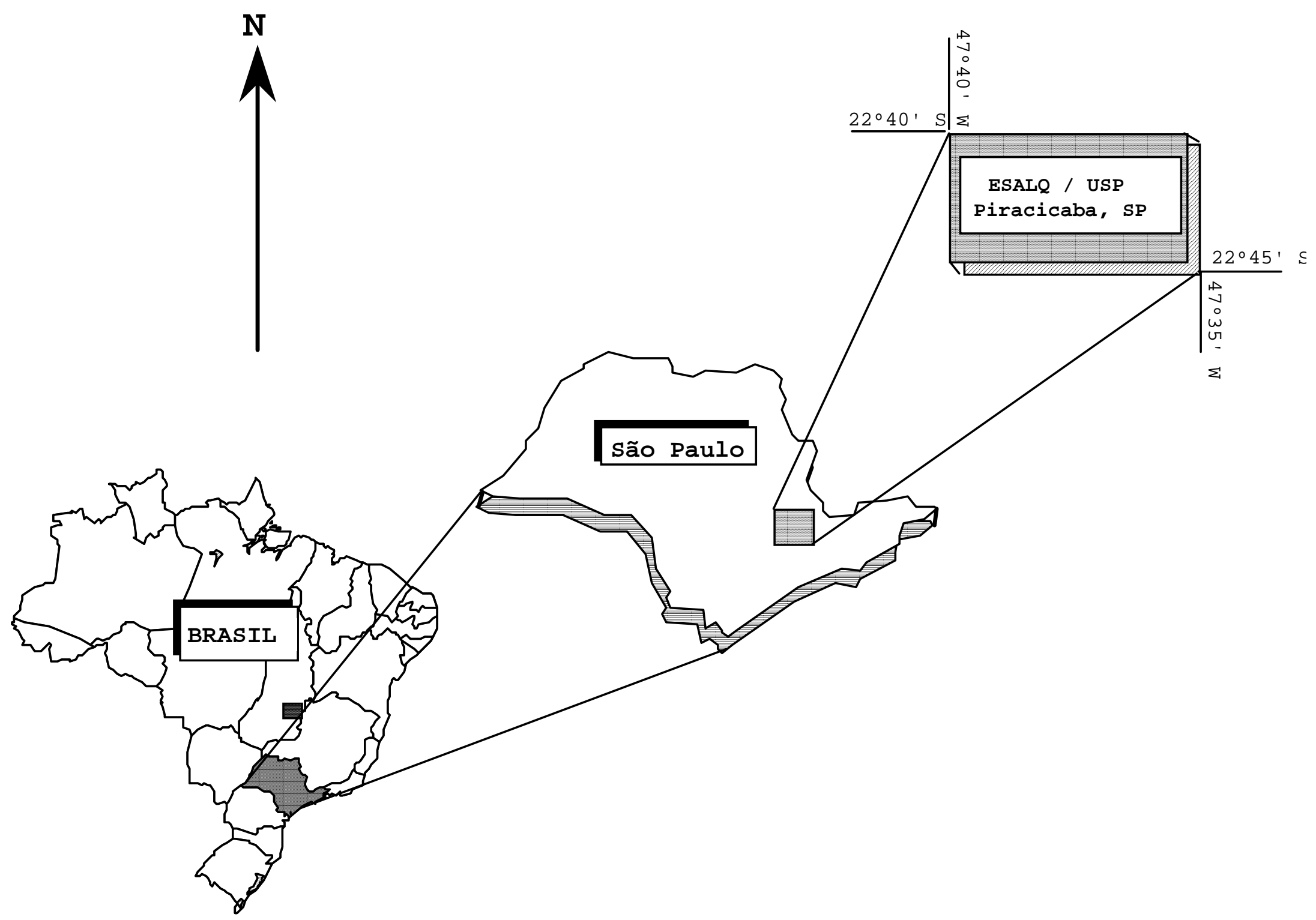

Figura 2 - Localização da área de estudo. 
Trimble Navigation. O equipamento constitui-se de: a) uma antena externa compacta $(15,4 \mathrm{~cm}$ de diâmetro e $8,9 \mathrm{~cm}$ de altura) com polarização circular e cobertura hemisférica; b) um receptor GPS Maxwell de 8 canais, capaz de receber os sinais da portadora L1 e do código C/A; e c) um coletor de dados modelo TDC1 com 640KB de memória (suficiente para registrar 30000 posições) e que opera com o software Asset Surveyor. Com este equipamento é possível realizar levantamentos dos tipos: estático, estático rápido e cinemático. Tem uma exatidão em nível de decímetros, quando utilizado o método de correção diferencial (DGPS) pós-processado e em boas condições de campo.

Como estação base foi utilizado o equipamento Pathfinder Community Base Station fabricado pela Trimble Navigation, que consiste de uma antena externa, um receptor GPS Maxwell de 12 canais conectado diretamente a um microcomputador portátil COMPAQ Contura Aero, com processador 486 DX2, 4MB de memória RAM e HD de 250MB. Nesse microcomputador foi instalado o programa PFCBS, que permite fazer o gerenciamento da estação base, bem como a criação e armazenamento dos arquivos com as informações recebidas dos satélites NAVSTAR referentes à períodos de uma hora, para posterior processamento dos dados. É um equipamento indispensável quando se utiliza a técnica de processamento DGPS.

\subsubsection{Microcomputador}

Para o processamento e a análise dos dados levantados no campo, foi utilizado um microcomputador Pentium II de $350 \mathrm{MHz}, 32 \mathrm{MB}$ de memória RAM e HD de $2 \mathrm{~GB}$, onde foram instalados os programas necessários para o processamento dos dados.

\subsubsection{Programas computacionais}

Para o planejamento da missão de campo, foi utilizado o programa Mission Planning da empresa Ashtech. Este programa faz, para um determinado local e período de tempo, uma projeção do sistema NAVSTAR, proporcionando ao usuário o 
número de satélites disponíveis acima da linha do horizonte, a sua geometria de posicionamento, bem como a diluição de precisão (DOP). Desta forma, o usuário poderá ir ao campo sabendo previamente quais os melhores dia e horário para se realizar o levantamento utilizando-se o receptor GPS.

Com o programa PFINDER, foi realizada a operação de pósprocessamento dos dados obtidos no campo, com o receptor GPS Pro XL da Trimble. Este programa permite transferir os dados do coletor para um microcomputador, faz a integração entre os dados da estação base com os obtidos pelo receptor utilizado no campo ("rover") para a determinação correção diferencial (DGPS) pós-processada, calcula a estatística dos resultados obtidos e, se necessário, mostra graficamente os dados coletados pelo receptor GPS e estação base, podendo ainda exporta-los para um SIG.

Também foram utilizados os programas TDAT, que faz as transformações de DATUM geodésico e coordenadas geográficas em TM (UTM, RTM e LTM) e/ou Topográficas Locais e TOPOESALQ 3.0-Plus que é um sistema para processamento de levantamentos planialtimétrico, para os cálculos do levantamento topográfico que serviu como referência para a comparação entre os dados.

\subsection{Métodos}

\subsubsection{Seleção das áreas de estudo}

Para a avaliação do desempenho do equipamento sob diferentes condições de cobertura vegetal, foram selecionadas quatro diferentes áreas: a) pastagem / testemunha; b) Eucalyptus saligna adulto (plantado em dezembro de 1969), na época da coleta de dados com espaçamento de 2,0 m; c) seringal policlonal, onde os principais clones são RRIM 600, IAN 873, PB 235 e GT 1, com idade variando entre 9 e 13 anos e espaçamento de 7,0 m x 3,0 m; e d) Pinus oocarpa (plantado em setembro de 1977). No interior das áreas selecionadas foram locados 6 pontos ao acaso, materializados por meio de piquetes de madeira e identificados por estacas. 


\subsubsection{Levantamento topográfico dos pontos}

Com a finalidade de obter valores de coordenadas planimétricas considerados como testemunhas, para os pontos locados nas diferentes áreas, esses pontos foram levantados segundo a NBR 13133 - Execução de Levantamento Topográfico. As poligonais foram da classe IVP, onde a medição angular foi feita pelo método das direções, com uma série de leituras conjugadas direta e inversa, horizontal e vertical e utilizando teodolito classe 2 e a medição linear foi feita com leituras recíprocas (vante e ré), com distanciômetro eletrônico classe 1 e controle taqueométrico com leitura dos três fios. O equipamento empregado, e já descrito no item 3.1.2.1., foi o PENTAX / PX-06D. Este levantamento utilizou como apoio os vértices implantados pela empresa BASE - Aerofotogrametria e Projetos, quando da implantação da Rede Básica de Referência Cadastral do Município de Piracicaba - SP, que para a determinação das coordenadas geográficas dos vértices utilizou o rastreamento de satélites com equipamento GPS. O método de rastreamento utilizado foi o diferencial com rastreamento de 1:30 hora, constelação de cinco a oito satélites e PDOP inferior a seis, utilizando-se quatro equipamentos simultaneamente (dois fixos e dois deslocados para os demais vértices). O Datum planimétrico utilizado foi o SF-23-1018 código 10981 do IBGE. Os cálculos foram desenvolvidos por meio do software Trinvec Plus GPS Survey, que forneceu as coordenadas geográficas no elipsóide WGS-84 que, posteriormente, foram transformadas em: a) geográficas no elipsóide SAD-69; b) geográficas no elipsóide Hayford - Córrego Alegre; e c) coordenadas no Sistema Topográfico Local, cujo plano é tangente nas coordenadas $\varphi=22^{\circ} 43^{\prime} 42,31651^{\prime \prime} \mathrm{S}$ e $\lambda=47^{\circ} 39^{\prime} 50,50392^{\prime \prime}$ W no elipsóide Hayford - Córrego Alegre, adotando-se a altitude 550,00m para o plano local. A exatidão das medições foram: a) horizontal $=10 \mathrm{~mm}+2 \mathrm{ppm} x$ distância $(\mathrm{km})$; b) azimute $=1 "+10 /$ comprimento da linha $(\mathrm{km})$; e c) vertical $=20 \mathrm{~mm}+2 \mathrm{ppm} x$ distância $(\mathrm{km})$. Tendo em vista que alguns destes pontos de apoio encontram-se próximo das áreas de estudo, foi fácil utilizá-los como estação base para o levantamento. 
O processamento dos dados do levantamento topográfico foi feito com o programa TOPOESALQ 3.0 Plus, que apresentou os coeficientes técnicos apresentados na Tabela 2.

Tabela 6. Coeficientes técnicos do levantamento planimétrico dos pontos

\begin{tabular}{|c|c|}
\hline $\begin{array}{c}\text { Número de vértices da poligonal principal: } \\
22\end{array}$ & $\begin{array}{c}\text { Perímetro percorrido: } \\
6018,792 \mathrm{~m}\end{array}$ \\
\hline $00^{\circ} 01^{\prime} 20^{\prime \prime}$ & Erro linear relativo: \\
\hline Erro angular de fechamento: & $1 / 28382$ \\
\hline Erro angular médio por estação: & Erro linear / mil: \\
$00^{\circ} 00^{\prime} 02^{\prime \prime}$ & 0,035 \\
\hline
\end{tabular}

\subsubsection{Teste preliminar para avaliação da taxa de aquisição com o receptor GPS}

Para uma avaliação preliminar da taxa de aquisição de dados com o receptor GPS, ou seja, intervalo de tempo para registro dos sinais, foi feito um teste sob condições de ausência de cobertura vegetal significativa e outras obstruções. Para tanto, o equipamento foi estacionado sobre um ponto de controle, com coordenadas previamente determinadas, e a aquisição foi feita variando-se o intervalo de registros (1 segundo, 10 segundos e 20 segundos) bem como o tempo de permanência sobre o ponto (de 10 segundos a 20 minutos). Com base nas informações obtidas neste teste é que se escolheu a taxa de aquisição de dados utilizada, bem como o tempo de permanência sobre cada ponto, como mostra a Tabela7. 
Tabela 7. Alguns resultados obtidos no teste preliminar para avaliação da taxa de aquisição de dados e tempo de permanência do equipamento sobre um ponto de controle.

\begin{tabular}{lll}
\hline \multicolumn{1}{c}{ Tratamento } & Longitude Média & Latitude Média \\
\hline T1 $=1,0 \mathrm{~s} \times 10,0 \mathrm{~s}$ & $47^{\circ} 37^{\prime} 14,737^{\prime \prime} \mathrm{W}$ & $22^{\circ} 42^{\prime} 26,018^{\prime \prime} \mathrm{S}$ \\
T2 $=1,0 \mathrm{~s} \times 30,0 \mathrm{~s}$ & $47^{\circ} 37^{\prime} 14,738^{\prime \prime} \mathrm{W}$ & $22^{\circ} 42^{\prime} 26,020^{\prime \prime} \mathrm{S}$ \\
T3 $=1,0 \mathrm{~s} \times 1,0 \mathrm{~min}$ & $47^{\circ} 37^{\prime} 14,737^{\prime \prime} \mathrm{W}$ & $22^{\circ} 42^{\prime} 26,021^{\prime \prime} \mathrm{S}$ \\
T4 $=10,0 \mathrm{~s} \times 1,5 \mathrm{~min}$ & $47^{\circ} 37^{\prime} 14,731^{\prime \prime} \mathrm{W}$ & $22^{\circ} 42^{\prime} 26,015^{\prime \prime} \mathrm{S}$ \\
T5 $=10,0 \mathrm{~s} \times 5,0 \mathrm{~min}$ & $47^{\circ} 37^{\prime} 14,723^{\prime \prime} \mathrm{W}$ & $22^{\circ} 42^{\prime} 26,018^{\prime \prime} \mathrm{S}$ \\
T6 $=10,0 \mathrm{~s} \times 10,0 \mathrm{~min}$ & $47^{\circ} 37^{\prime} 14,736^{\prime \prime} \mathrm{W}$ & $22^{\circ} 42^{\prime} 26,020^{\prime \prime} \mathrm{S}$ \\
T7 $=20,0 \mathrm{~s} \times 3,0 \mathrm{~min}$ & $47^{\circ} 37^{\prime} 14,732^{\prime \prime} \mathrm{W}$ & $22^{\circ} 42^{\prime} 26,012^{\prime \prime} \mathrm{S}$ \\
T8 $=20,0 \mathrm{~s} \times 10,0 \mathrm{~min}$ & $47^{\circ} 37^{\prime} 14,727^{\prime \prime} \mathrm{W}$ & $22^{\circ} 42^{\prime} 26,011^{\prime \prime} \mathrm{S}$ \\
T9 $=20,0 \mathrm{~s} \times 20,0 \mathrm{~min}$ & $47^{\circ} 37^{\prime} 14,723^{\prime \prime} \mathrm{W}$ & $22^{\circ} 42^{\prime} 26,0144^{\prime \prime} \mathrm{S}$ \\
\hline
\end{tabular}

3.2.4. Levantamento das coordenadas planimétricas dos pontos com o receptor GPS

Com as informações citadas e de acordo com Gilbert (1997b) e Deckert \& Bolstad (1996), que sugerem a obtenção de 60 a 500 registros por ponto, após a avaliação da taxa de aquisição citada no item anterior e apoiado nas observações de Sumpter (1993) e Liu \& Brantigan (1995), Bueno (1995) e Sá (2000), decidiu-se levantar os pontos por meio do método estático e operar o equipamento com taxa de aquisição constante e igual a 1 segundo, variando o tempo de permanência sobre os pontos (1 minuto, 5 minutos e 10 minutos) localizados nas áreas com os diferentes tipos de cobertura vegetal. Também levou-se em consideração qual o período do dia mais adequado para o levantamento dos pontos com relação ao número de satélites disponíveis e PDOP, sendo que o planejamento da missão para o levantamento dos 
pontos com o receptor GPS foi feito utilizando-se software Mission Planning (APÊNDICE 1). Os levantamentos dos pontos foram realizados nas seguintes datas:

- Pastagem: dias 14 e 16 de dezembro de 1998;

- Seringueira: dia 17 de dezembro de 1998;

- Pinus: dia 18 de dezembro de 1998;

- Eucalipto: dias 18 e 21 de dezembro de 1998.

Nos dias acima relacionados, antes da ida ao campo, instalou-se a antena receptora da estação base sobre um marco de coordenadas conhecidas (47 $37^{\prime} 48,08741^{\prime \prime}$ W e $22^{\circ} 42^{\prime} 40,52591^{\prime \prime}$ S), situado no teto do Laboratório de Hidráulica do Departamento de Engenharia Rural - ESALQ / USP (portanto livre de obstruções), que estava conectada a um receptor GPS Maxwell de 12 canais e este ao microcomputador, onde estava instalado o programa PFCBS, que faz o gerenciamento da estação base e permite a criação e armazenamento dos arquivos com as informações recebidas dos satélites NAVSTAR, para posterior processamento dos dados.

Os dados de campo foram levantados pelo método estático rápido, com o receptor GPS Pathfinder Pro XL, já descrito anteriormente, que fora previamente ajustado para operar com uma taxa de aquisição igual a 1 segundo, PDOP $\leq 5$ e ângulo de elevação de $15^{\circ}$. Com o auxílio de um bipé, onde foi fixada a antena, os 6 pontos materializados por piquetes e identificados por estacas, localizados nos 4 tipos de cobertura vegetal (pastagem, eucalipto, seringueira e pinus), foram levantados em sequência (1 minuto, 5 minutos e 10 minutos) e as informações armazenadas no coletor de dados para posteriormente se fazer a correção diferencial (DGPS).

Terminado o levantamento de campo, os dados armazenados no coletor e os arquivos criados pela Pathfinder Community Base Station foram processados com o auxílio do programa PFINDER, instalado em um microcomputador do Laboratório de Geoprocessamento do Departamento de Engenharia Rural - ESALQ / USP, e na seguinte sequência: 
1. Criação de um projeto: é o ambiente de trabalho onde serão descarregados e processados os dados de um determinado levantamento;

2. Configuração do PFINDER: com relação a unidades de medida, datum, sistema de coordenadas etc;

3. Transferência dos arquivos do coletor TDC1 para o microcomputador, com o auxílio do cabo serial apropriado;

4. Combinação dos arquivos da estação base: como já foi citado anteriormente, a estação base gera arquivos referentes a uma hora de rastreamento dos satélites NAVSTAR, assim, se o trabalho de campo foi realizado por um período de tempo superior, haverá necessidade de se combinar estes arquivos (extensão ssf), que passarão a se chamar combined.ssf ;

5. Correção diferencial (DGPS): a correção diferencial é realizada arquivo por arquivo coletado no campo (extensão ssf), utilizando os dados da estação base (combined.ssf) e que irão gerar os arquivos corrigidos (extensão cor);

6. Estatística dos dados: finalmente, para cada arquivo corrigido utilizou-se a função estatística, que fornece o número de registros utilizados para o cálculo, longitude e latitude mínimas, máximas médias e desvios padrão (vide Anexo A). Os valores médios obtidos é que foram utilizados como sendo as coordenadas planimétricas obtidas com o receptor GPS.

\subsubsection{Transformação dos dados}

Para poder avaliar a exatidão do equipamento GPS utilizado na determinação das coordenadas planimétricas dos pontos de interesse, foi necessário compará-las com coordenadas dos mesmos pontos determinadas por meio de outra metodologia, reconhecidamente mais precisa e exata. Estas "coordenadas de controle" foram obtidas por meio de um levantamento topográfico conforme descrito no item 3.2.2. 
As coordenadas de controle e as coordenadas obtidas pelo GPS, estão em sistemas diferentes e, consequentemente, não são comparáveis. Este problema foi resolvido efetuando-se transformações de forma que as coordenadas ficassem todas no mesmo sistema. Para tanto, neste trabalho foi utilizado o programa TDAT, que transformou as coordenadas geográficas fornecidas pelo sistema GPS e referidas ao DATUM WGS-84 para o plano topográfico local (x, y). Estas coordenadas pertencem a um sistema cartesiano $(\mathbf{X}, \mathbf{Y}, \mathbf{Z})$, com origem num ponto de altitude média da região considerada. O eixo $\mathbf{Z}$ orientado segundo a "vertical" na origem e o eixo $\mathbf{Y}$ orientado para o Norte Geográfico.

As coordenadas obtidas pelo método topográfico convencional também estão referenciadas a um sistema cartesiano, com o eixo $\mathbf{Z}$ orientado segundo a "vertical". Sendo a região pequena em relação à Terra na sua totalidade, o efeito do desvio vertical, assim como a convergência entre verticais não é considerável e o eixos $\mathbf{Z}$ de ambos os sistemas podem ser considerados paralelos.

O levantamento topográfico foi feito com origem em outro ponto e a orientação do eixo $\mathbf{Y}$ foi dada pelo Norte magnético.

Do anteriormente exposto deduz-se que os eixos $(\mathbf{X}, \mathbf{Y})$ de ambos os sistemas acham-se rotacionados e suas origens transladadas. Para que o sistema referencial seja o mesmo para todas as coordenadas, deve ser feita uma "translação" e uma "rotação" de eixos, o que matematicamente se resolve por meio das equações:

$$
\begin{aligned}
& \mathbf{X}=\mathbf{E} \times \mathbf{b}+\mathbf{N} \times \mathbf{a}+\mathbf{c} \\
& \mathbf{Y}=-\mathbf{E} \times \mathbf{a}+\mathbf{N} \times \mathbf{b}+\mathbf{d}
\end{aligned}
$$

- $\mathbf{X}$ e $\mathbf{Y}=>$ são as coordenadas geográficas obtidas com GPS e transformadas em topográficas pelo software TDAT;

- E e $\mathbf{N}=>$ são as coordenadas topográficas obtidas no levantamento de campo;

- $\mathbf{a}$ e $\mathbf{b}=>$ são respectivamente o seno e o coseno do ângulo de rotação " $\varphi$ ";

- c e d => são as coordenadas de translação. 
Nestas equações há 4 incógnitas: $\mathbf{a}, \mathbf{b}, \mathbf{c}$ e d; duas correspondentes à translação (c e d) e duas à rotação (a e b). Para resolve-las são necessárias 4 equações. Estas equações foram obtidas considerando-se dois pontos de controle de coordenadas conhecidas e substituindo seus valores em ambos os sistemas nas equações 1 e 2 . Resolvido o sistema foram determinados os quatro parâmetros em questão.

Utilizando as equações 1 e 2, agora com os coeficientes conhecidos, foram calculadas as coordenadas planas referenciadas ao Norte Geográfico, a partir das coordenadas topográficas referenciadas ao Norte magnético. Estas novas coordenadas estavam em condições de serem comparadas com as obtidas a partir do GPS.

\subsubsection{Determinação do erro de posicionamento}

Para calcular o erro de posicionamento fez-se uma analogia com o erro linear de fechamento utilizado nos cálculos das poligonais fechadas onde, segundo Domingues (1979), as somas algébricas das projeções $N p$ ou $E p$ de uma poligonal fechada, sobre os respectivos eixos $N$ e $E$, devem ser nulas (teorema de Carnot). Tem-se então o erro de fechamento, definido pelas seguintes expressões:

$$
\begin{gathered}
\varepsilon_{N}=\Sigma N_{p+}-\Sigma N_{p-} \\
\varepsilon_{E}=\Sigma E_{p^{+}}-\Sigma E_{p-}
\end{gathered}
$$

Assim, de acordo com a teoria dos erros, pode-se definir o erro linear de fechamento como sendo:

$$
\varepsilon_{L}=\sqrt{\varepsilon_{N}^{2}+\varepsilon_{E}^{2}}
$$

Considerando então $\Delta \mathrm{x}$ como sendo a diferença entre as coordenadas $\mathrm{X}$ obtidas pelo método topográfico convencional e com o receptor GPS e $\Delta y$ a diferença entre as coordenadas Y, o erro de posicionamento será:

$$
\text { Erro de posicionamento }=\sqrt{\Delta \mathrm{x}^{2}+\Delta \mathrm{y}^{2}}
$$


Assim, para cada um dos seis pontos localizados sob os 4 tipos diferentes de cobertura vegetal foram obtidos 3 valores diferentes de erro de posicionamento, referentes aos 3 tempos de permanência utilizados (1 minuto, 5 minutos e 10 minutos). Os pontos foram identificados como mostra a Tabela 8 .

Tabela 8. Identificação dos pontos utilizados nos levantamentos.

\begin{tabular}{|c|c|c|c|}
\hline Pastagem & Seringueira & Pinus & Eucalipto \\
\hline P11 & S11 & $\mathrm{Pi} 11$ & E11 \\
\hline P15 & S15 & $\mathrm{Pi} 15$ & E15 \\
\hline P110 & S110 & Pi110 & E110 \\
\hline P21 & S21 & $\mathrm{Pi} 21$ & E21 \\
\hline P25 & S25 & $\mathrm{Pi} 25$ & E25 \\
\hline P210 & S210 & $\mathrm{Pi} 210$ & E210 \\
\hline P31 & S31 & Pi31 & E31 \\
\hline P35 & S35 & Pi35 & E35 \\
\hline P310 & S310 & Pi310 & E310 \\
\hline P41 & S41 & $\mathrm{Pi} 41$ & E41 \\
\hline P45 & S45 & $\mathrm{Pi} 45$ & E45 \\
\hline P410 & S410 & Pi410 & E410 \\
\hline P51 & S51 & Pi51 & E51 \\
\hline P55 & S55 & $\mathrm{Pi} 55$ & E55 \\
\hline P510 & S510 & Pi510 & E510 \\
\hline P61 & S61 & Pi61 & E61 \\
\hline P65 & S65 & Pi65 & E65 \\
\hline P610 & S610 & Pi610 & E610 \\
\hline
\end{tabular}

Obs.: As letras indicam o tipo de cobertura vegetal, o primeiro número a identificação do ponto e o outro número o tempo de permanência com o receptor GPS.

\subsubsection{Análise estatística dos resultados}

\subsubsection{Análise da variância e testes de significância}

Para testar a influência da cobertura vegetal e tempo de medição, na determinação de posição por meio de GPS, utilizou-se um delineamento inteiramente ao acaso, modelo de Gauss e Markov (Montgomery, 1993). 
A variável de resposta do experimento foi o erro de posicionamento obtido no levantamento por GPS em relação ao levantamento topográfico convencional.

Os tratamentos principais foram as coberturas vegetais:

$$
\begin{array}{ll}
\text { 1- Pastagem } & \text { 2- Seringueira } \\
\text { 3- Pinus } & \text { 4- Eucalipto }
\end{array}
$$

cada um repetido 6 vezes, constituindo 24 parcelas experimentais, e tomadas medidas da variável resposta em 3 tempos:

$$
\begin{aligned}
& \text { 1- um minuto } \\
& \text { 3- dez minutos }
\end{aligned}
$$

constituindo 72 unidades experimentais. (Tabela 9)

Assim, o modelo matemático adotado foi o de delineamento inteiramente ao acaso com parcelas subdivididas:

$$
Y_{i j k}=m+C_{i}+e_{i j}+T_{k}+(C T)_{i k}+E_{i j k}
$$

onde:

$Y_{i j k}=$ valor observado da variável erro de posição referente ao i-ésimo tratamento (cobertura vegetal) no j-ésima repetição no k-ésimo tempo;

$m$ = fator fixo, estimado pela média geral;

$C_{i}=$ efeito da i-ésima cobertura vegetal;

$e_{i j}=$ erro aleatório correspondente às parcelas (variação do acaso sobre as observações da i-ésima cobertura vegetal na j-ésima repetição), supostos homocedásticos, independentes e normalmente distribuídos.

$T_{k}=$ efeito do k-ésimo tempo;

$(C T)_{i k}=$ efeito da interação da i-ésima cobertura vegetal com o k-ésimo tempo;

$\varepsilon_{i j k}=$ erro aleatório correspondente às subparcelas (variação do acaso sobre as observações da i-ésima cobertura vegetal, k-ésimo tempo, na j-ésima repetição), supostos homocedásticos, independentes e normalmente distribuídos. 
Tabela 9. Esquema de análise da variância e teste F para tratamentos

\begin{tabular}{|c|c|c|c|c|}
\hline $\begin{array}{l}\text { Causas da } \\
\text { Variação }\end{array}$ & G.L. & S.Q. & Q.M. & $\mathbf{F}$ \\
\hline Coberturas & 3 & SQ Coberturas & QM Coberturas & $\begin{array}{l}\text { QM Coberturas /QM } \\
\text { Resíduo(A) }\end{array}$ \\
\hline Resíduo (A) & 20 & SQ Resíduo (A) & QM Resíduo (A) & \\
\hline Parcelas & (23) & SQ Parcelas & & \\
\hline Tempos & 2 & SQ Tempos & QM Tempos & $\begin{array}{l}\text { QM Tempos /QM } \\
\text { Resíduo(B) }\end{array}$ \\
\hline Cob. x Temp. & 6 & SQ Cob. x Temp. & QM Cob. x Tempo & $\begin{array}{c}\text { QM Cobertura } \mathrm{x} \\
\text { Tempo/QM Resíduo(B) }\end{array}$ \\
\hline Resíduo (B) & 40 & SQ Resíduo (B) & QM Resíduo (B) & \\
\hline Total & 71 & SQ Total & & \\
\hline
\end{tabular}

A razão QM Tratamentos/QM Res. testa as hipóteses:

- $\mathrm{H}_{0}$ : não existe diferença entre as médias de coberturas (QM Coberturas / QM Resíduo (A) );

- $\mathrm{H}_{0}$ : não existe diferença entre as médias de tempos de medição (QM Tempos / QM Resíduo (B) );

- $\mathrm{H}_{0}$ : não existe diferença entre as médias da interação de coberturas e tempos de medição (QM Coberturas x Tempos / QM Resíduo (B) );

Dado que o fator Cobertura Vegetal é qualitativo, sempre que o teste $\mathrm{F}$ detectou diferença significativa entre suas médias ou entre as médias da interação, foi feito o detalhamento da análise por meio do Teste de Comparações Múltiplas de Tukey, e por meio do Teste de Dunnett, considerando o nível Pastagem do fator Cobertura Vegetal como testemunha.

Para o fator Tempo e suas interações, como se trata de fator quantitativo, a bibliografia consultada recomenda que o detalhamento da análise da variância seja feito por meio de estudo do comportamento da variável (erro de posição) em função do 
tempo, utilizando-se análise de regressão polinomial e ajuste de curvas. Com base nesse estudo, foram ajustados os modelos lineares e quadráticos.

\subsubsection{Análise exploratória dos dados}

Para que os modelos de análise descritos tenham validade e os testes tenham poder, são necessárias serem satisfeitas as pressuposições:

- homogeneidade de variâncias, ou seja, só podem ser comparados tratamentos com variâncias homogêneas entre si;

- independência dos erros;

- erros com distribuição normal (ou aproximadamente normal).

Para testar essas pressuposições procedeu-se à análise exploratória de dados, por meio de:

- Teste de homogeneidade de variâncias: utilizou-se o teste do $F_{\text {máx }}$, que consiste em obter a razão entre a maior e a menor variância de tratamentos e compará-la com um valor tabelado:

$$
F_{\max }=\frac{s_{\max }^{2}}{s_{\min }^{2}} \sim F_{(k t r a t ; v-1 \text { rep. })}
$$

Se o valor obtido for maior que o tabelado, rejeita-se a hipótese de que as variâncias de tratamentos são homogêneas, havendo necessidade de se estudar se essa heterogeneidade pode ser eliminada com uma transformação dos dados ou não. Se o valor obtido for menor que o tabelado, não se rejeita a hipótese de homogeneidade de variâncias.

- Análise gráfica dos resíduos: consiste em plotar num diagrama de dispersão os valores estimados pelo modelo da análise da variância versus os resíduos padronizados (erro referente a cada observação dividido pelo desvio padrão amostral). A forma desse gráfico permite detectar a falta de independência e existência de heterogeneidade regular (que pode ser eliminada por meio do 
uso de uma transformação adequada) ou irregular (que não permite transformação, quando se recomenda o uso da estatística não-paramétrica). $O$ intervalo dos resíduos padronizados detecta se há algum(ns) valor(es) desviando-se da normalidade. Consideram-se normalmente distribuídos os resíduos que estiverem no intervalo de -3 a 3 .

- Diagrama de "ramos e folhas": ordenação dos dados de forma programada para mostrar sua distribuição aproximada, dispersão, assimetria, curtose, agrupamento de valores e, principalmente, detecção de "outliers" (dados discrepantes) e sua localização, alertando para possíveis problemas não notados durante o experimento (p.e., material estranho ao experimento).

Sempre que alguma das pressuposições foi violada, procurou-se a transformação potência adequada (Hoaglin et al., 1983) para a análise paramétrica, e fezse também a análise não-paramétrica para comprovação. 


\section{RESULTADOS E DISCUSSÃO}

\subsection{Coordenadas dos pontos levantados.}

As coordenadas obtidas pelo método topográfico convencional e com GPS, para todos os pontos levantados nas diferentes condições de cobertura vegetal, com os diferentes tempos de permanência, bem como os erros de posicionamento, são apresentados nas Tabelas 10, 11, 12 e 13. No Anexo A encontram-se as coordenadas GPS corrigidas de todos os pontos, sem transformação de sistema, e respectivas estatísticas

Uma análise preliminar dos dados das tabelas citadas mostra, como era de se esperar e concordando com Gerlach (1989), Petersen (1990), Evans et al. (1992), Lance (1993), Liu \& Brantigan (1995), Deckert \& Bolstad (1996), Naesset (1999), Sigrist et al. (1999) e Naesset et al. (2000), que os menores erros de posicionamento foram obtidos na área de pastagem, estando estes erros dentro do esperado tratando-se de um equipamento da categoria submétrico, e confirmando a influência das diferentes coberturas vegetais (seringueira, pinus e eucalipto) no posicionamento planimétrico dos pontos levantados.

Outro aspecto importante foi que, de maneira geral, um maior tempo de permanência sobre os pontos propiciou um menor erro de posicionamento para a maioria dos pontos, independentemente da cobertura vegetal, concordando com Petersen (1990), Sumpter (1993) e Liu \& Brantigan (1995). 

Tabela 10. Coordenadas topográficas e GPS e erro de posicionamento para os pontos levantados na área teste ocupada por pastagem.

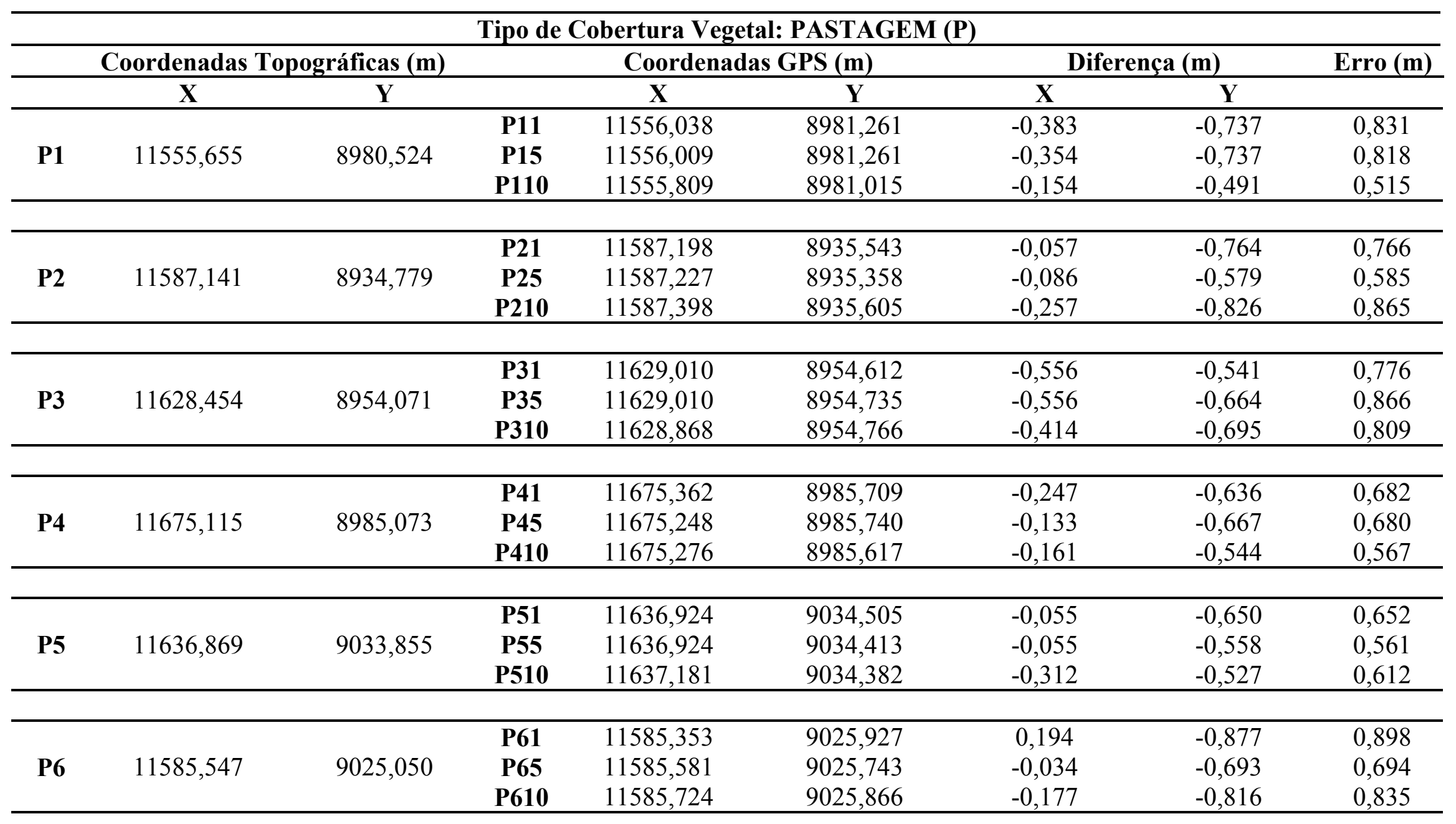


Tabela 11. Coordenadas topográficas e GPS e erro de posicionamento para os pontos levantados na área teste ocupada por seringueira.

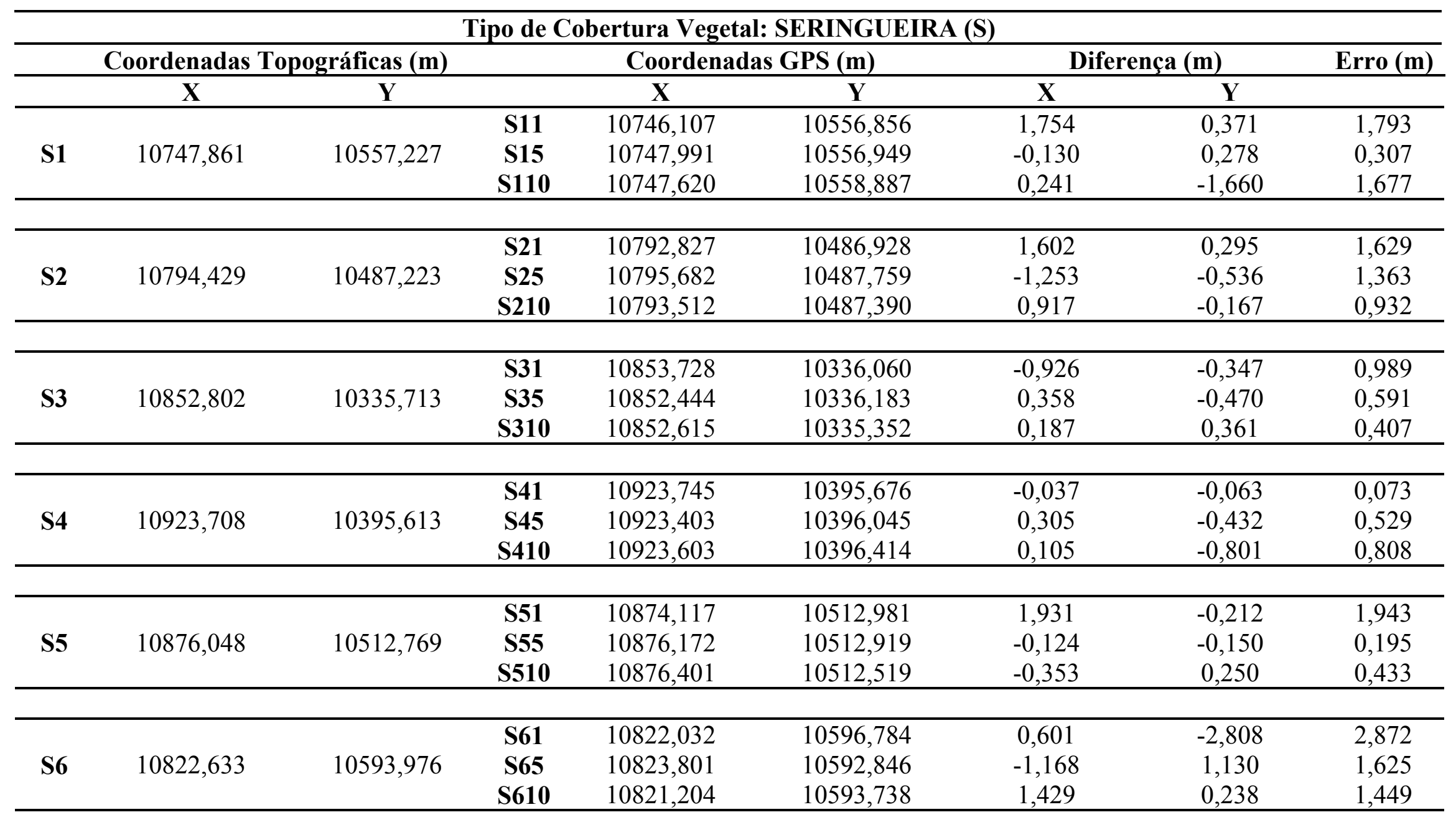


Tabela 12. Coordenadas topográficas e GPS e erro de posicionamento para os pontos levantados na área teste ocupada por pinus.

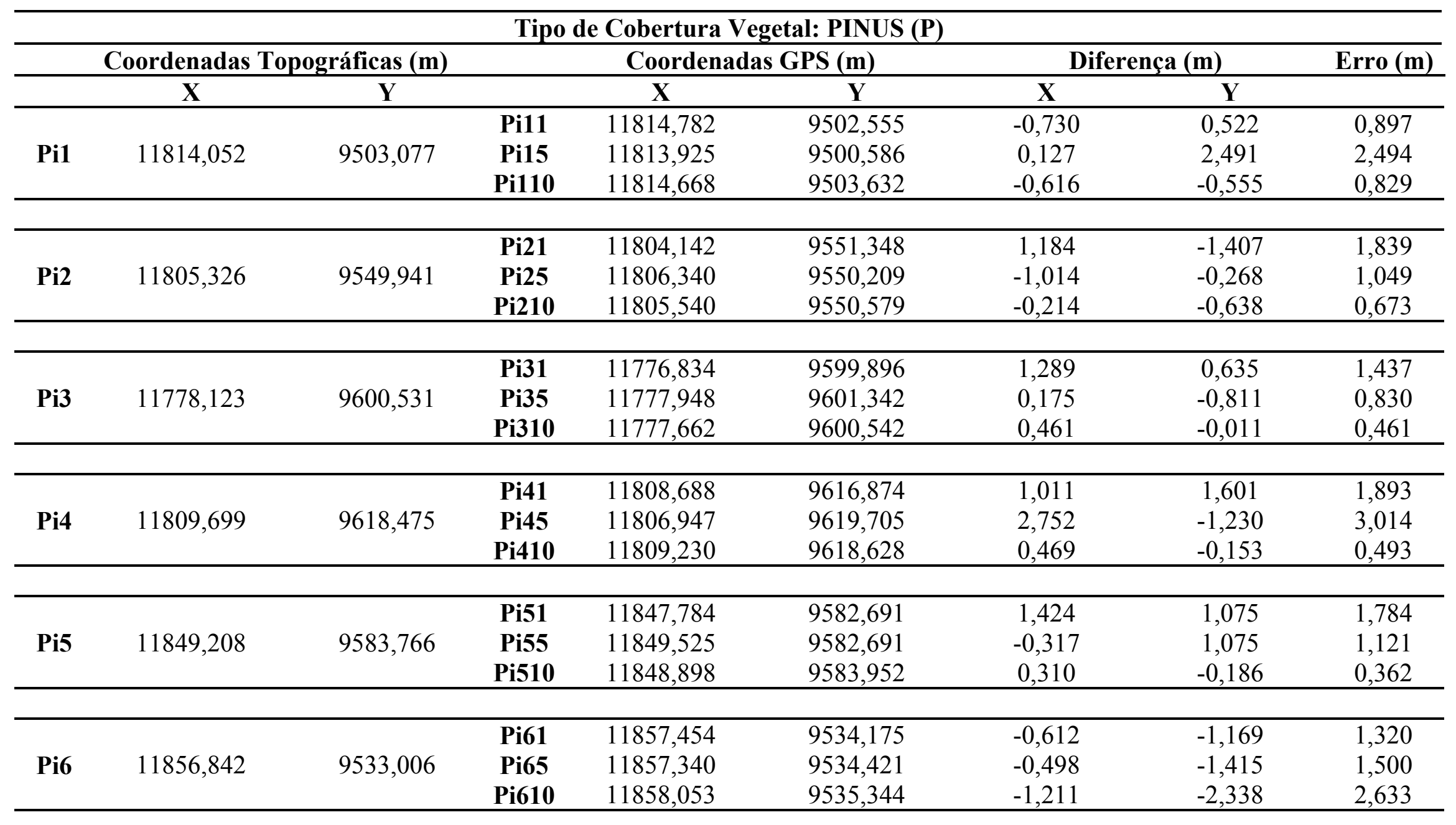


Tabela 13. Coordenadas topográficas e GPS e erro de posicionamento para os pontos levantados na área teste ocupada por eucalipto.

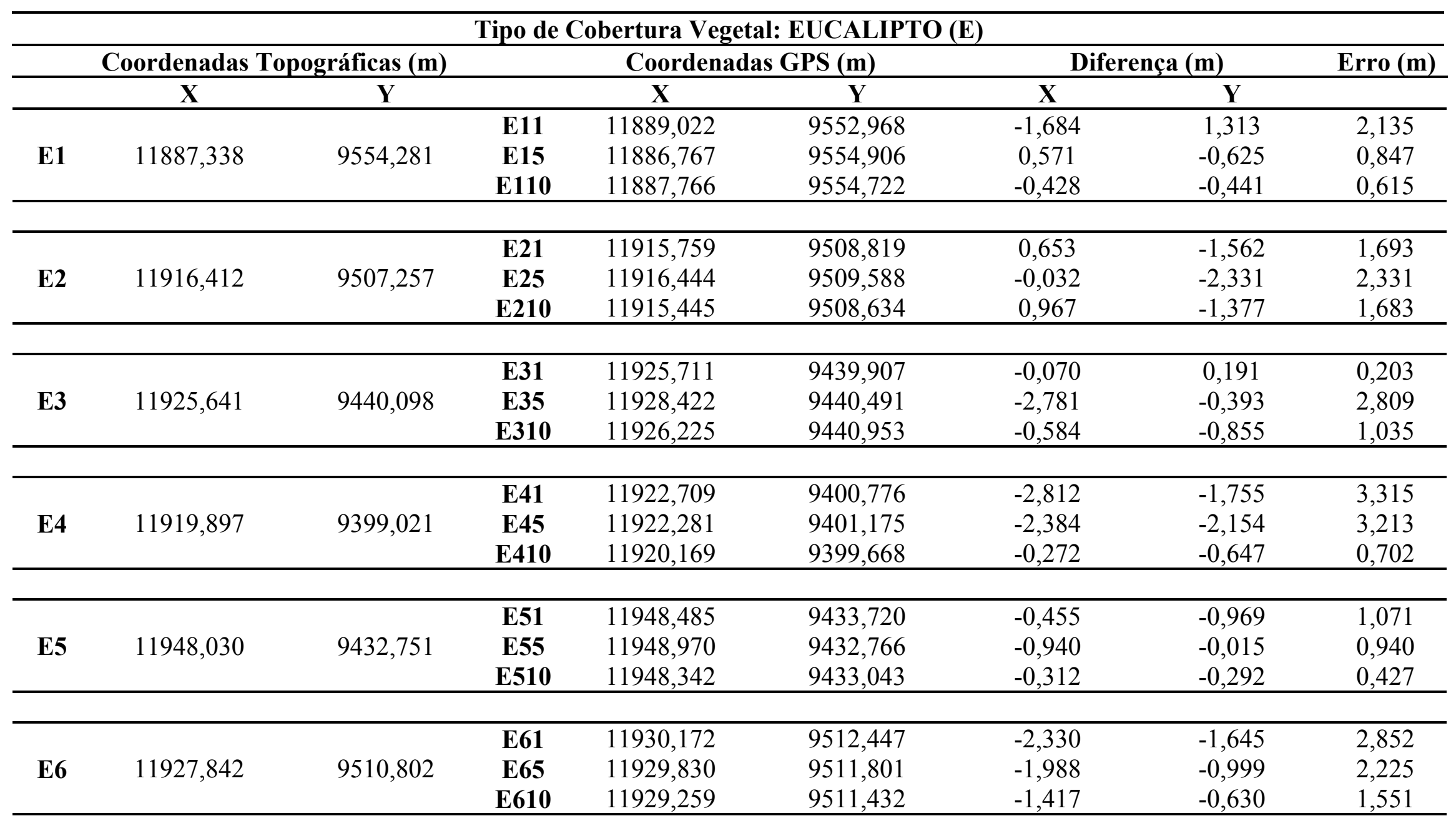




\subsection{Influência da cobertura vegetal.}

A Tabela 14 apresenta as médias de registros de posicionamento por unidade de tempo armazenados pelo receptor GPS. Como a taxa de aquisição de dados foi fixada em 1 segundo, o número de registros obtidos no levantamento dos pontos da área com pastagem corresponde ao máximo possível em cada tempo utilizado. A influência da cobertura vegetal fica então comprovada, quando comparamos estes registros com os obtidos nas áreas com outro tipo de vegetação (seringueira, pinus e eucalipto), onde os valores foram sempre menores, o que concorda com os resultados obtidos por Gerlach (1989), Petersen (1990), Evans et al. (1992), Lance (1993), Liu \& Brantigan (1995), Deckert \& Bolstad (1996), Naesset (1999), Sigrist et al. (1999) e Naesset et al. (2000).

A interferência causada pela cobertura vegetal que ocasionou, em média, para o tempo de 1 minuto a perda de 7,2\% dos registros, 18,7\% para 5 minutos e $14,1 \%$ para 10 minutos, poderia ser explicada pela própria barreira física causada pelo dossel da vegetação, como sugere Lance (1993), ou até uma eventual mudança na geometria da constelação de satélites que, ao interferir com a "diluição da precisão" (DOP), ocasionaria a perda de sinal (principalmente para os tempos de 5 min. e $10 \mathrm{~min}$.), como explicam Pessoa (1997) e Naesset (1999).

Tabela 14. Médias de registros de posicionamento armazenados pelo receptor GPS por unidade de tempo.

\begin{tabular}{ccccc}
\hline & Pasto & Seringueira & Pinus & Eucalipto \\
\hline $\mathbf{1}$ minuto & 60 & 59 & 53 & 55 \\
\hline $\mathbf{5}$ minutos & 300 & 235 & 257 & 240 \\
\hline $\mathbf{1 0}$ minutos & 600 & 540 & 484 & 523 \\
\hline
\end{tabular}




\subsection{Análise estatística}

Com a finalidade de melhor entender a influência que a cobertura vegetal e o tempo de permanência sobre os pontos levantados, tiveram na captação dos sinais emitidos pelos satélites GPS, bem como se houve diferença entre as vegetações e os tempos escolhidos procedeu-se a análise estatística dos dados.

\subsubsection{Análise exploratória dos dados}

O valor observado no teste de $\mathrm{F}_{\text {máx }}$ para a variável erro de medição $(157,04)$, foi maior que o tabelado $(29,9)$, ao nível de $5 \%$ de significância, com 12 e 5 graus de liberdade respectivamente. Esse resultado aponta para a presença de heterocedasticidade, ou seja, uma violação importante nas pressuposições do modelo de Gauss e Markov.

A análise gráfica dos resíduos para a variável não transformada e com transformação raiz quadrada, apresentada na Figura 3, permite afirmar que as pressuposições de independência (através da forma do gráfico), de normalidade (através dos intervalos dos resíduos padronizados) não foram violadas, e que a pressuposição homogeneidade de variâncias foi restabelecida com a transformação raiz quadrada.

O gráfico de resíduos para a variável transformada através da função raiz quadrada, transformação indicada pela técnica Transformação Potência (Figura 11), mostra uma diminuição da heterocedasticidade, porém, não a resolução do problema. 
4.3.2. Análise da variância e testes de significância

\subsubsection{Análise da variância}

Em função da violação da pressuposição de homocedasticidade do modelo de Gauss e Markov adotado, os dados foram analisados aplicando-se a transformação raiz quadrada, recomendada pela aplicação da técnica Transformação Potência e, para confirmação de que a transformação aumentou o poder dos testes, realizou-se também a análise dos dados por meio de estatística não-paramétrica.

Após a aplicação dessas duas técnicas de análise, transformação raiz quadrada e estatística não-paramétrica, pode-se constatar que os resultados praticamente não mudam para qualquer uma das duas opções.

A análise da variância para a variável erro de medição, dados transformados com raiz quadrada, encontra-se na Tabela 15.

Tabela 15. Análise da variância e teste $\mathrm{F}$ para a variável erro de medição (com transformação raiz quadrada), em função dos fatores (causas da variação) cobertura e tempo de medição.

\begin{tabular}{|c|c|c|c|c|c|}
\hline CAUSAS DA VARIAÇÃO & G.L. & S.Q. & Q.M. & VALOR F & PROB. $>\mathrm{F}$ \\
\hline \multirow{2}{*}{$\begin{array}{l}\text { COBERTURA } \\
\text { RESÍDUO (A) }\end{array}$} & 3 & 1,4564778 & 0,4854926 & 3,8648 & 0,02449 \\
\hline & 20 & 2,5123795 & 0,1256190 & & \\
\hline \multirow{4}{*}{$\begin{array}{l}\text { PARCELAS } \\
\text { TEMPO } \\
\text { COB*TEM } \\
\text { RESÍDUO (B) }\end{array}$} & 23 & 3,9688573 & & & \\
\hline & 2 & 0,6772253 & 0,3386126 & 4,0644 & 0,02407 \\
\hline & 6 & 0,7673444 & 0,1278907 & 1,5351 & 0,19122 \\
\hline & 40 & 3,3324410 & 0,0833110 & & \\
\hline TOTAL & 71 & 8,7458679 & & & \\
\hline \multicolumn{4}{|c|}{ MÉDIA GERAL $=1,041881$} & & \\
\hline \multicolumn{4}{|c|}{ COEFICIENTE DE VARIAÇÃO $(\mathrm{A})=19,640 \%$} & & \\
\hline \multicolumn{4}{|c|}{ COEFICIENTE DE VARIAÇÃO $(\mathrm{B})=27,703 \%$} & & \\
\hline
\end{tabular}


O quadro de análise da variância (Tabela 15) mostra que houve diferença significativa, pelo teste $\mathrm{F}$, para os fatores cobertura e tempo, com aproximadamente $98 \%$ de confiança. A interação esteve próxima à significância e nesses casos recomenda-se o seu desdobramento, ou seja, comparar as coberturas para cada um dos tempos e os tempos em cada uma das coberturas.

\subsubsection{Testes de comparação para médias de coberturas vegetais}

\section{Teste de Tukey}

O resultado da aplicação desse teste para todos os tempos e para cada um dos tempos de medição, pode ser observado na Tabela 16.

Os resultados da Tabela 16 mostram que, levando-se em consideração todos os tempos, a cobertura eucalipto apresentou a maior média para a variável erro de medição $(1,65 \mathrm{~m})$, diferindo, com 95\% de confiança, da cobertura pastagem, que apresentou a menor média $(0,72 \mathrm{~m})$. Essa foi a única diferença estatisticamente significativa detectada. Quando se consideraram as médias de coberturas em todos os tempos, observa-se que, embora apresentando a maior média, o eucalipto somente diferiu estatisticamente de pastagem.

Na mesma Tabela 16 observa-se o comportamento das coberturas vegetais nos diferentes tempos de medição.

Tabela 16. Comparações entre coberturas vegetais pelo teste de Tukey baseadas em médias da variável erro de posicionamento.

\begin{tabular}{|c|c|c|c|c|c|c|c|c|c|c|}
\hline \multirow{3}{*}{$\begin{array}{c}\text { Cobertura } \\
\text { Vegetal } \\
\text { Eucalipto }\end{array}$} & \multicolumn{9}{|c|}{ Tempo de Medição (minutos) } & \multirow{2}{*}{$\begin{array}{c}\text { Média Geral } \\
\text { (todos os tempos) }\end{array}$} \\
\hline & \multicolumn{3}{|c|}{1} & \multicolumn{3}{|c|}{5} & \multicolumn{3}{|c|}{10} & \\
\hline & 1,88 & $a$ & $\mathrm{~A}$ & 2,06 & $\mathrm{a}$ & $\mathrm{A}$ & 1,00 & $\mathrm{a}$ & $\mathrm{A}$ & 1,65 a $\mathrm{A}$ \\
\hline Pinus & 1,53 & $\mathrm{a}$ & $\mathrm{A}$ & 1,67 & $\mathrm{ab}$ & $\mathrm{A}$ & 0,91 & $\mathrm{a}$ & $\mathrm{A}$ & $1,37 \mathrm{ab} \quad \mathrm{A}$ \\
\hline Seringueira & 1,55 & $\mathrm{a}$ & $\mathrm{A}$ & 0,77 & $\mathrm{~b}$ & $\mathrm{~A}$ & 0,95 & $\mathrm{a}$ & $\mathrm{A}$ & 1,09 ab A \\
\hline Pastagem & 0,77 & $\mathrm{a}$ & $\mathrm{A}$ & 0,70 & $\mathrm{~b}$ & $\mathrm{~A}$ & 0,70 & $\mathrm{a}$ & $\mathrm{A}$ & $0,72 \quad \mathrm{~b} \quad \mathrm{~A}$ \\
\hline
\end{tabular}

Obs.: Médias seguidas por alguma letra em comum não diferem pelo Teste de Tukey ao nível de 95\% de confiança (letras minúsculas) ou 99\% de confiança (letras maiúsculas). 
Confirmando o resultado da análise da variância, observa-se que o teste de Tukey não detectou diferença significativa entre as médias de coberturas dentro de tempos, exceção feita, ao nível de 5\%, para coberturas dentro do tempo de 5 minutos, onde o eucalipto foi significativamente superior à pastagem e à seringueira e igual ao pinus. O pinus, por sua vez, não diferiu estatisticamente da maior média nem das menores.

\section{Teste de Dunnett}

Um outro teste de significância aplicado ao fator cobertura vegetal foi o de Dunnett, recomendado para comparações de tratamentos com uma testemunha, sendo a pastagem considerada como testemunha (Tabela 17). As conclusões não mudaram substancialmente em relação ao teste de Tukey, porém, surgiram novas diferenças, pelo fato do teste de Dunnett ser mais sensível que o de Tukey para comparações com testemunha.

Tabela 17. Comparações entre coberturas vegetais pelo teste de Dunnett em médias da variável erro de medição, considerando pastagem como testemunha.

\begin{tabular}{|c|c|c|c|c|c|c|c|c|}
\hline \multirow{3}{*}{$\begin{array}{c}\begin{array}{c}\text { Cobertura } \\
\text { Vegetal }\end{array} \\
\text { Eucalipto }\end{array}$} & \multicolumn{6}{|c|}{ Tempo de Medição (minutos) } & \multirow{2}{*}{\multicolumn{2}{|c|}{$\begin{array}{c}\text { Média Geral } \\
\text { (todos os tempos) }\end{array}$}} \\
\hline & \multicolumn{2}{|c|}{1} & \multicolumn{2}{|c|}{5} & \multicolumn{2}{|l|}{10} & & \\
\hline & 1,88 & * $\mathrm{n}$ & 2,06 & $* \quad *$ & $1,00 \mathrm{~ns}$ & ns & $1,65 *$ & $*$ \\
\hline Pinus & 1,53 & $\mathrm{~s} n$ & 1,67 & * ns & $0,91 \mathrm{~ns}$ & ns & $1,37 *$ & ns \\
\hline Seringueira & 1,55 & ns $\mathrm{n}$ & 0,77 & ns $\mathrm{ns}$ & $0,95 \mathrm{~ns}$ & $\mathrm{~ns}$ & $1,09 \mathrm{~ns}$ & ns \\
\hline $\begin{array}{l}\text { Pastagem } \\
\text { (Testemunha) }\end{array}$ & 0,77 & & 0,70 & & 0,70 & & 0,72 & \\
\hline
\end{tabular}

Nas comparações das médias do fator cobertura, para todos os tempos, foi evidenciada pelo teste de Dunnett diferença significativa entre pastagem e pinus, ao nível de 95\% de confiança, enquanto que pelo teste de Tukey elas foram consideradas 
iguais. Entre pastagem e eucalipto, que pelo teste de Tukey apresentavam diferença com 95\% de confiança, pelo teste de Dunnett evidenciou-se diferença com 99\% de confiança.

Quando se estudaram as coberturas dentro dos tempos, observou-se que pelo teste de Dunnett foi evidenciada diferença entre a pastagem e o eucalipto com 95\% de confiança no tempo de um minuto (pelo Tukey não foi detectada diferença entre eles). Dentro de 5 minutos do fator tempo, ocorreu diferença entre pastagem e pinus com 95\% de confiança (pelo Tukey não houve diferença entre eles) e entre pastagem e eucalipto uma diferença com $99 \%$ de confiança (pelo Tukey a confiança dessa diferença era de 95\%). Aos 10 minutos, o teste de Dunnett foi concordante com o teste de Tukey, isto é, não foi detectada diferença entre pasto e as demais coberturas vegetais.

4.3.2.3. Detalhamento da análise para tempos de medição por meio de da análise de regressão polinomial

O estudo dos tempos para todas as coberturas vegetais, mostrou uma tendência linear decrescente, altamente significativa (com mais de 99\% de confiança), relacionando o fator tempo de medição com a variável de resposta erro de posição (Figura 5).

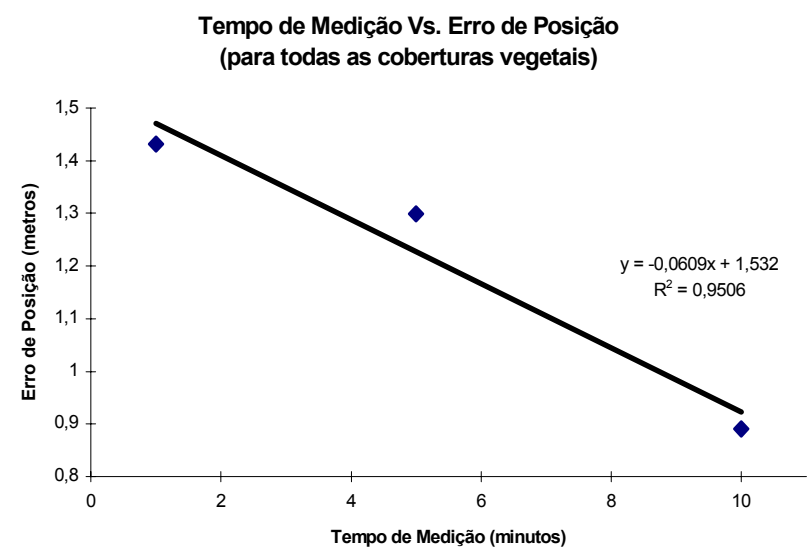

Figura 5 - Relação linear entre o fator tempo de medição e a variável de resposta erro de posicionamento. 
Quando se desdobraram os graus de liberdade da interação para visualizar a tendência do fator tempo dentro de cada cobertura vegetal, observou-se, para todas as coberturas, uma tendência linear decrescente, com confiança de $96 \%$ para o pinus, $95 \%$ para o eucalipto, e sem significância estatística para a pastagem e para a seringueira. Na Figura 6 são apresentadas essas tendências, bem como as retas ajustadas e os coeficientes de determinação.

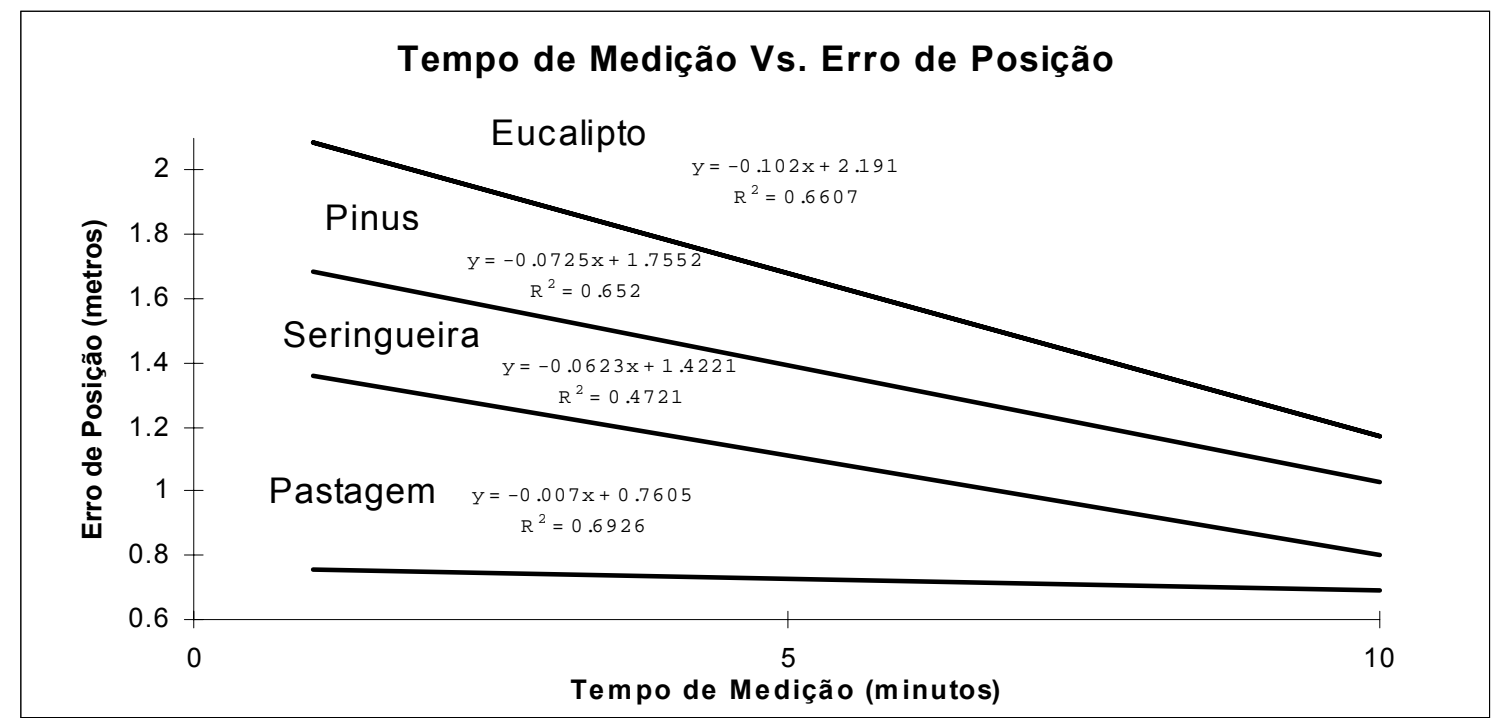

Figura 6 - Ajuste da relação entre o fator tempo de medição e a variável de resposta erro de posicionamento para cada uma das coberturas vegetais.

O gráfico de tendências, para cada uma das coberturas vegetais, mostra que aumentando o tempo de medição, o erro de posição tende a confluir com o erro obtido para a pastagem (testemunha). Nestes gráficos também pode-se visualizar uma tendência, a ocorrência de maiores erros de posicionamento para o eucalipto, seguido do pinus, seringueira e pastagem, com um máximo de diferenças para o tempo de medição de 1 minuto e mínimo para 10 minutos.

Apesar da análise estatística mostrar diferenças no erro de posicionamento em apenas algumas situações (Tabelas 16 e 17), pode-se observar que o tempo de permanência de 10 minutos foi o que apresentou melhores resultados, independentemente do tipo de cobertura vegetal e que, portanto, dentro da metodologia 
empregada seria o tempo de permanência recomendado. Estes resultados mostram que a escolha do método de levantamento GPS é fundamental para obtenção de bons resultados, o que concorda com as observações feitas por Lance (1993), Sumpter (1993), Liu e Brantigan (1995), Bueno (1995), Gilbert (1997b), Naesset (1999) e Sigrist et al. (1999). 


\section{CONCLUSÕES}

De acordo com a metodologia empregada e os resultados obtidos, as principais conclusões foram:

- foi possível separar as exatidões de posicionamento planimétrico conforme o tipo de cobertura vegetal em dois grupos: sem e com cobertura arbórea, confirmando assim a interferência do dossel na recepção dos sinais emitidos pelos satélites GPS;

- o aumento do tempo de permanência, de maneira geral, melhorou a exatidão de posicionamento planimétrico, o que ratifica a escolha da metodologia de levantamento como sendo fundamental para obtenção de bons resultados de posicionamento. 


\section{REFERÊNCIAS BIBLIOGRÁFICAS}

AL-GAADI, K.A.; AYERS, P.D. Integrating GIS and GPS into a spatially variable rate herbicide application system. Applied Engineering in Agriculture, v.15, n.4, p.255262, Jul. 1999.

AUGUST, P.; MICHAUD, J. LABASH, C.; SMITH, C. GPS for environmental applications - accuracy and precision of locational data. Photogrammetric Engineering and Remote Sensing, v.60, n.1, p.41-45, Jan. 1994.

BALASTREIRE, L.A.; ELIAS, A.I.; AMARAL, J.R. Agricultura de precisão: mapeamento da produtividade da cultura do milho. Engenharia Rural, v.8, n.1, p.97-111, jul. 1997.

BAUER, W.D.; SCHEFCIK, M. Using differential GPS to improve crop yields. GPS World, v.5, n.2, p.38-41, 1994.

BENEVENTO, A. Disponibilidade seletiva do GPS desligada! E agora?. infoGEO. Curitiba, v.3, n.14, p.43, jul/ago. 2000.

BERGSTROM, G.C. GPS in forest management. GPS World, p.46-49, Sep/Oct. 1990.

BLITZKOW, D. NAVSTAR/GPS - Um desafio tornado realidade. In: SIMPÓSIO BRASILEIRO DE GEOPROCESSAMENTO, 3., São Paulo, 1995. Anais. São Paulo: EP/USP, 1995. p.429-462. 
BUENO, R.F. Avaliação da precisão do sistema NAVSTAR/GPS. São Paulo, 1995. 209p. Dissertação (Mestrado) - Escola Politécnica, Universidade de São Paulo.

BUENO, R.F. O GPS sem S/A. infoGEO. Curitiba, v.3, n.15, p.26-27, set/out. 2000.

DECKERT, C.; BOLSTAD, P.V. Forest canopy, terrain, and distance effects on global positioning system point accuracy. Photogrammetric Engineering and Remote Sensing, v.62, n.30, p.317-321, Mar. 1996.

DOMINGUES, F.A.A. Topografia e astronomia de posição: para engenheiros e arquitetos. São Paulo: Editora Mc Graw Hill do Brasil, 1979. 403p.

DRUMMOND, S.T.; FRAISSE, C.W.; SUDDUTH, K.A. Combine harvest area determination by vector processing of GPS position data. Transactions of the ASAE, v.42, n.5, p.1221-1227, Sep/Oct. 1999.

EVANS, D.L.; CARRAWAY, R.W.; SIMMONS, G.T. Use of global positioning system (GPS) for forest plot location. Southern Journal of Applied Forestry, v.16, n.2, p.67-70, 1992.

GERLACH, F. L. Global positioning system - input to GIS. In: NATIONAL CONVENTION OF THE SOCIETY OF AMERICAN FORESTERS. Spokane, 1989. p.52-57. (paper)

GILBERT, C. Erros em GPS : o que você pode e o que você não pode corrigir. Fator GIS. Curitiba, v.5, n.17, p.62-63, 1997a.

GILBERT, C. GPS - Performance sob coberturas vegetais. Fator GIS. Curitiba, v.5, n.18, p.52-53, $1997 \mathrm{~b}$. 
GREER, J.D. The view from above. Journal of Forestry, Bethesda, v.91, n.8, p.10-14, 1993.

HOAGLIN, D.C.; MOSTELLER, F.; TUKEY, J.W. Análise exploratória de dados:técnicas robustas. Lisboa: John Wiley \& Sons, 1983. 446p.

IBGE. Especificações e normas gerais para levantamentos GPS. Fator GIS. Curitiba, v.2, n.6, p.31-34, 1994.

KOVACH, K.L.; VAN DYKE, K.L. GPS in 10 years. Microwave Journal, v.41, n.2, p.22, Feb. 1998.

KRUCZINSKY, L. R.; JASUMBACK, A. Forestry management applications - Forest Service experiences with GPS. Journal of Forestry. Bethesda, v.91, n.8, p.20-24, Aug. 1993.

LANCE, K. Bringing technology down to Earth - A GPS consumer guide. Journal of Forestry. Bethesda, v.91, n.8, p.17-19, 1993.

LEICK, A. GPS satellite surveying. Maine: John Wiley \& Sons, 1990. 352p.

LIU, C.J.; BRANTIGAN, R.D. Using differential GPS for forest traverse surveys. Canadian Journal of Forest Research - Revue Canadienne de Recherche Forestiere, v.25, n.11, p.1795-1805, Nov. 1995.

LONG, D.S.; DEGLORIA, S.D.; GALBRAITH, J.M. Use of the Global Positioning System in soil survey. Journal of Soil and Water Conservation, v.46, n.4, p.293297, Jul/Aug. 1991. 
McCORMICK, C.M. Mapping exotic vegetation in the Everglades from large-scale aerial photographs. Photogrammetric Engineering and Remote Sensing, v.65, n.2, p.179-184, Feb. 1999.

MONTGOMERY, D.C. Design and analysis of experiments. New York, John Wiley \& Sons. 1993. 578p.

NAESSET, E. Point accuracy of combined pseudorange and carrier phase differential GPS under forest canopy. Canadian Journal and Forest Research-Revue Canadienne de Recherche Forestiere, v.29, n.5, p.547-553, May. 1999.

NAESSET, E.; BJERKE, T.; OVSTEDAL, O.; RYAN, L.H. Contributions of differential GPS and GLONASS observations to point accuracy under forest. Photogrammetric Engineering and Remote Sensing, v.66, n.4, p.403-407, Apr. 2000.

PESSOA, L.M. da C. Efeitos que degradam a precisão GPS. Fator GIS. Curitiba, v.5, n.17, p.28-29, 1997.

PETERSEN, C. Into the woods with GPS. GPS World, v.1, n.6, p.31-36, nov/dec. 1990.

REMPEL, R. S.; RODGERS, A. R.; ABRAHAM, K.F. Performance of a GPS animal location system under boreal forest canopy. Journal of Wildlife Management, v.59, n.3, p.543-551, 1995.

SÁ, N. C. de GPS - Fundamentos e aplicações. São Paulo: IAG/USP, Departamento de Geofísica, 2000. 98p. 
SEGANTINE, P.C.L. GPS - Sistema de posicionamento global. São Carlos: EESC, Departamento de Transportes, 1998. 181p.

SIGRIST, P.; COPPIN, P. HERMY, M. Impact of forest canopy on quality anti accuracy of GPS measurements. International Journal of Remote Sensing, v.20, n.18, p.3595-3610, Dec. 1999.

SILVA, J.D. da; ABDON, M.D. Delimitation of the Brazilian Pantanal and its subregions. Pesquisa Agropecuária Brasileira, v.33, p.1703-1711, Out. 1998.

SILVA, J.D. da; ABDON, M.D.; SILVA, M.P. da; ROMERO, H.R. Deforestations survey in the Brazilian Pantanal in 1990/91. Pesquisa Agropecuária Brasileira, v.33, p.1739-1745, Out. 1998.

STAFFORD, J.V. GPS in agriculture - A growing market! Journal of Navigation, v.52, n.1, p.60-69, Jan. 1999.

SUMPTER, C. Property surveys using GPS. Journal of Forestry. Bethesda, v.91, n.8, p.26-27, 1993.

TURNER, L.W.; UDAL, M.C.; LARSON, B.T.; SHEARER, S.A. Monitoring cattle behavior and pasture use with GPS and GIS. Canadian Journal of Animal Science, v.80, n.3, p.405-413, Sep. 2000.

VAN SICKLE, J. GPS for land surveyors. Michigan: Ann Arbor Press, 1996. 209p.

VETTORAZZI, C. A; ANGUlO FILHO, R.; COUTO, H. T. Z. Sistema de posicionamento global - GPS. Engenharia Rural. Piracicaba, v.5, n.2, p.61-70, 1994. 
WEBSTER, T.M.; CARDINA, J. Accuracy of a global positioning system (GPS) for weed mapping. Weed Technology, v.11, n.4, p.782-786, Oct/Dec. 1997. 